Universidade de Brasília

Instituto de Relações Internacionais

Dissertação em Relações Internacionais

\title{
A China e os "PALOP": uma análise das relações sino-africanas com enfoque nos países de língua oficial portuguesa
}


NANAHIRA DE RABELO E SANT'ANNA

\section{A China e os "PALOP": uma análise das relações sino- africanas com enfoque nos países de língua oficial portuguesa}

Monografia de final de curso Instituto de Relações Internacionais

Orientador: José Flávio Sombra Saraiva 


\section{Índice}

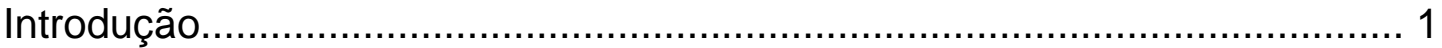

A evolução das relações sino-africanas .................................................. 6

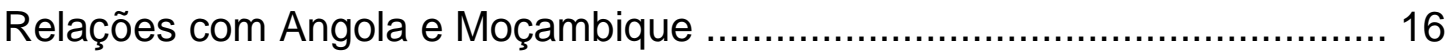

China e Angola: energia e crescimento......................................... 18

China e Moçambique: agricultura e infra-estruturas........................... 27

Relações com Cabo Verde, Guiné-Bissau e São Tomé e Príncipe ............... 34

Cabo Verde: zona econômica e turismo .............................................. 36

Guiné-Bissau: recuperação agrícola................................................ 41

São Tomé e Príncipe: superando obstáculos políticos........................ 46

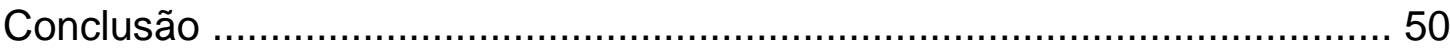

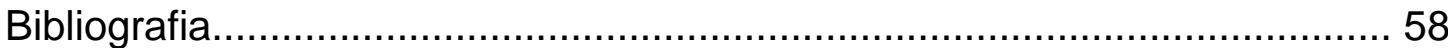




\section{Banca Examinadora}

Antônio Carlos Moraes Lessa

Wolfgang Adolf Karl Dopke

José Flávio Sombra Saraiva (Orientador) 


\section{INTRODUÇÃO}

A China emerge no cenário internacional com altas taxas de crescimento econômico, e atua na expansão e intensificação de relações econômicocomerciais com várias partes do globo. A grande demanda por recursos naturais e energéticos faz com que o dragão se movimente em direção a fontes de longo prazo de sustentação, muitas delas localizadas em países do continente africano. As modernas relações sino-africanas apresentam um histórico de mais de meio século de cooperação, iniciadas nos movimentos de independência das novas nações da África. No entanto, verifica-se, nos últimos anos, um envolvimento diferente entre as duas partes em questão, a partir das atuais necessidades de um país que conquista posição de importante global player e da positiva recepção da incursão chinesa pelo continente negro.

$O$ presente trabalho enfoca a incremento cooperativo chinês com os países da África cuja língua oficial é a portuguesa. Angola, Cabo Verde, GuinéBissau, Moçambique e São Tomé e Príncipe são membros da Comunidade dos Países de Língua Portuguesa (CPLP), grupo que se completa com Brasil, Portugal e Timor Leste. O continente africano, em geral, apresenta-se favorável a estratégias de cooperação com o gigante asiático, que busca fornecedores de recursos naturais, matérias-primas e petróleo, assim como oportunidades comerciais e novos mercados para suas exportações. Aos países africanos interessa a obtenção de fundos para a realização de obras de infra-estrutura e desenvolvimento, a fim de superar a defasagem tecnológica e reforçar seu peso político. Para a análise, buscou-se comparar em que medida as considerações acima se aplicam aos países africanos lusófonos.

O trabalho se apóia numa perspectiva que combina dois níveis de análise, referentes a duas imagens retratadas pelo autor neo-realista Kenneth Walt ${ }^{1}$, sem, contudo, defender a abordagem do realismo estrutural. Os níveis estatal e sistêmico se unem para a melhor análise do movimento de aproximação entre China e África, tratando especialmente do incremento cooperativo com os países africanos lusófonos. Não apenas considera-se como importantes as ações tomadas pelas entidades dotadas de soberania,

\footnotetext{
${ }^{1}$ WALTZ, Kenneth N. "Theory of International Politics". New York: Mc Graw-Hill, 1979.
} 
como também se analisa a influência dos movimentos a nível global no comportamento estatal. Destaca-se a globalização como fator do sistema internacional com grandes repercussões sobre os Estados, e as políticas tomadas por cada um deles em resposta a tal dinâmica. No relacionamento sino-africano, considera-se que as decisões de cada Estado, em matéria de política externa, não apenas são funções das instituições, arranjos sociais, cultura e organização política a nível doméstico, como também resultam da posição ocupada pelos Estados na estrutura internacional.

A pesquisa aproxima-se dos esclarecimentos da interdependência complexa, ao referir às várias conexões internacionais existentes a nível mundial, em que coexistem uma pluralidade de atores, e ao lançar as relações internacionais para a área da economia política, enfatizando as relações comerciais e a escassez de recursos. Robert Keohane mantém considerações realistas ao referir-se à relevância dos entes estatais e à permanência de um caráter anárquico do meio internacional, mas afirma possibilidades de diferentes padrões de relações entre os Estados ${ }^{2}$. Assim, o conflito não é resultado necessário da premissa de que os mesmos buscam realizar 0 interesse próprio; a cooperação é possível e pode redundar desse autointeresse.

A cooperação entre China e os países africanos lusófonos tanto decorre das intenções dos atores estatais envolvidos, quanto corresponde a uma resposta às dinâmicas da globalização, contexto em que os vários Estados do meio internacional se encontram cada vez mais interdependentes, relacionando-se por fluxos diversos. Comércio, investimentos e ajuda ao desenvolvimento são destacados neste trabalho, que adota uma abordagem predominantemente liberal da economia política internacional - uma que une forças de mercado e políticas estatais na explicação dos padrões verificados, e que defende $o$ alcance de níveis de crescimento e desenvolvimento econômico e social a partir de reformas direcionadas ao livre mercado.

A pesquisa privilegia o período iniciado com o lançamento do Fórum de Cooperação China-África (FOCAC) em 2000, a representar um importante

\footnotetext{
2 KEOHANE, Robert O. "Power and Interdependence. World Politics in Transition." Boston: Little Brown, 1977.
} 
marco do atual estado das relações sino-africanas. Mais especificamente em relação aos países da CPLP, o reforço da cooperação é notado com a primeira Conferência Ministerial do Fórum para a Cooperação Econômica e Comercial entre China e os Países de Língua Portuguesa, ocorrido em outubro de 2003, em Macau. As iniciativas e os desenvolvimentos anteriores e subseqüentes, apoiados formalmente ou não por políticas de cada Estado ou pelos mecanismos multilaterais citados, serão analisados em duas partes: na primeira, são retratados os movimentos em Angola e Moçambique, que recebem maior atenção e geram maior repercussão a nível internacional; em fase posterior, o trabalho segue com análises sobre os restantes três países africanos de língua portuguesa, Cabo Verde, Guiné-Bissau e São Tomé e Príncipe, que também têm se beneficiado da estratégia chinesa, apesar de a cooperação ainda estar a um nível relativamente baixo. Antes da análise das relações entre China e cada PALOP tomado individualmente, a evolução das relações entre a China e o continente africano em geral é esclarecida em pontos que ajudam a explicar o atual estado da cooperação, a partir de raízes que remontam a séculos anteriores.

$O$ recente incremento cooperativo entre as duas regiões apresenta significativas repercussões tanto para as partes em questão quanto em outras partes do mundo, entre as quais ganham destaque as ricas democracias do mundo desenvolvido, encontradas nos Estados Unidos e no continente europeu. Os debates sobre a atuação chinesa nos países africanos giram em torno de considerações de padrões legais, ambientais e trabalhistas na exploração dos recursos pelas empresas da China. Tem se notado que o país é bem recebido pelas nações da África nas atividades de comércio, investimentos e ajuda, tendo em vista as possibilidades de prosperidade para países pouco desenvolvidos, sendo que a China, apenas um entre os vários países em busca de matérias-primas pelo mundo, é vista, geralmente, como poder benigno na região. A atuação chinesa é comparada às estratégias dos países desenvolvidos do Ocidente, assim como os movimentos em política econômica dos países africanos para alcançarem níveis de crescimento e desenvolvimento a partir das oportunidades oferecidas por períodos de prosperidade econômica do sistema capitalista são analisados ao longo dos anos. 
Após apresentar uma perspectiva evolutiva das relações sino-africanas, a pesquisa acessa em que medida as relações entre a China e os países africanos participantes da CPLP têm alcançado os níveis planejados em seus encontros, de modo a inserir tais relações no âmbito do crescente incremento cooperativo entre o gigante asiático e a África, estratégia dividida em atividades comerciais, fluxos de investimento e fundos de ajuda. Verifica-se quais destas categorias caracterizam o relacionamento chinês com cada país selecionado, e como têm avançado seus padrões, a fim de se traçar os perfis das relações, suas possíveis repercussões e perspectivas futuras, tanto para as partes quanto a nível mundial. O debate entre obtenção de benefícios da abertura econômica, com geração de crescimento econômico, e sua transformação em bons níveis de desenvolvimento é tratado pela complementação entre as esferas política e econômica. Tal método de análise busca uma coompreensão mais complexa do debate entre comércio, investimentos e desenvolvimento, seguindo a afirmação de Keohane de que "um entendimento mais profundo em eventos macroeconômicos é alcançado pela combinação de argumentos econômicos com a análise de conflitos de interesses e o exercício de poder, que ocorrem entre diferentes sociedades nacionais e a economia política internacional”.

A partir de uma análise que segue o objeto de estudo da economia política internacional, no que considera a importância da interação entre forças de mercado e políticas estatais ${ }^{4}$, o trabalho leva em conta o fenômeno da globalização e os movimentos em direção ao isolamento ou à maior integração à economia global tomados pelos países escolhidos, assim como busca compreender condições sociais, políticas locais e legados histórico-culturais. Procura-se acessar em que medida os fluxos de comércio, investimentos e ajuda recebidos pelos países africanos a partir de iniciativas tomadas por parte dos dois lados, têm capacidade de se traduzir em melhores níveis de desenvolvimento econômico e social para os países africanos. O trabalho analisa de modo comparativo as áreas mais evidentes do relacionamento entre

\footnotetext{
${ }^{3}$ KEOHANE, Robert O. "Economics, Inflation and the Role of the State: Political Implications of the McCracken Report." World Politics 31, no. 1, October 1978, pp.108-128.

${ }^{4}$ GILPIN." Global Political Economy”. Princeton, NJ: Princeton University Press, 2001.
} 
a China e cada um dos PALOP, de modo a traçar o recente estado das atividades de cooperação e discutir repercussões e potencialidades de um movimento que ganha atenção internacional no início deste século XXI. 


\section{A EVOLUÇÃO DAS RELAÇÕES SINO-AFRICANAS}

Os países africanos da CPLP, organização cujas idéias criadoras apontavam para um diálogo tricontinental entre países unidos por uma herança histórica, pelo idioma comum e por uma visão compartilhada do desenvolvimento e da democracia, têm recebido ultimamente significativa atenção de um gigante que caminha rumo à posição de potência global da Ásia. As relações sino-africanas ganham maior dinamismo num contexto em que o enorme crescimento econômico da China faz o país aumentar sua demanda por recursos naturais e energéticos e oportunidades comerciais, e uma das regiões onde Pequim está com os olhos postos é a África. A aposta nos países de língua portuguesa é forte por oferecerem segurança energética, fornecerem recursos naturais e apresentarem um mercado potencial de milhões de consumidores. Percebe-se que, nos últimos anos, a atividade econômica chinesa no continente africano tem crescido significativamente, afirmação válida para os cinco PALOP analisados.

Trata-se de um momento em que, no continente africano em geral, pela primeira vez em décadas, o otimismo com crescimento econômico supera o desânimo com guerras e miséria. O crescimento médio do continente foi de 6,1\% em 2007 - maior do que o da América Latina, de 5,2\% -, com previsão de $7 \%$ para $2008^{5}$. Apesar de muitas dinâmicas negativas ainda se fazerem presentes na África, boas notícias surgem em diferentes cantos do continente, e revelam uma nova e pouco conhecida faceta africana, que anima setores políticos e empresariais de todo o mundo em busca de parcerias lucrativas. Aproveitando a alta nos preços das commodities, como petróleo e minérios, o continente começa a atrair investimentos externos, boa parte dos quais são financiados pela China. Assim, a potência emergente do século XXI redescobre a África tirando-a do esquecimento político e econômico a que estava relegada desde o fim da Guerra Fria.

\footnotetext{
5 "O Renascimento Africano". O Estado de São Paulo, 17/12/2007.
} 
As relações comerciais entre as duas partes têm uma longa história, datando mesmo antes das expedições promovidas por Zheng $\mathrm{He}$, na dinastia Ming, num período que remonta às primeiras décadas do século $\mathrm{XIV}^{6}$. Já 0 estabelecimento das modernas relações sino-africanas se dá em meados do século $X X$, quando o apoio econômico, técnico e militar aos movimentos de libertação e independência presentes no continente africano faziam parte da política externa chinesa, influenciada pelo contexto de Guerra Fria ${ }^{7}$. Após a fundação da República Popular da China, em 1949, seguiram-se três décadas em que a presença chinesa no continente africano em geral se deu a partir do próprio legado que a China apresentava em matéria de exploração colonial e experiência de libertação, a promover ligações com países da África que passavam pelo processo de independência. Apesar de não apresentar a quantidade de recursos dos superpoderes da Guerra Fria, o país empregou energias no apoio da África independente; com afinidades anti-imperialistas, proveu técnicas, treinamento militar, modesta ajuda econômica e melhorias em infra-estrutura ${ }^{8}$.

A política externa chinesa objetivava estender a influência política da China sobre o continente africano, desenvolver relações oficiais com os países recém-independentes e formar uma frente única com os países e os povos da África, a fim de lutar contra o imperialismo, o colonialismo e o hegemonismo. Em Angola e Moçambique, estimulava-se a luta não apenas contra 0 colonialismo, mas também movimentos de libertação em relação a dominações racistas. Na medida de suas possibilidades, a China forncecia ao povo africano ajuda material, armamentista e financeira, de acordo com o objetivo estratégico socialista de "sustentar a revolução mundial". Guerras de libertação nacional e revolução eram encorajadas como parte de uma frente unida contra os dois

\footnotetext{
${ }^{6}$ O governo Ming, entre 1405 e 1433, promoveu sete experições navais, por meio das quais o imperador Yong'le estendia a presença chinesa em várias partes do globo. Nas expedições que alcançaram o continente africano, o explorador Zheng He trocava seda e procelana por animais africanos como girafas e zebras.

7 JIA, Annie. "Roundtable probes the politics of China's large-scale investments in Africa" Stanford Report, 16.05.2007, disponível em http://news-service.stanford.edu/.

${ }^{8}$ ASHBY, Tom. "China seeks 'strategic partnership' with Africa”. The Boston Globe, 27.04.2006, disponível em http://www.boston.com/.
} 
superpoderes em concorrentes na época, nomeadamente Estados Unidos e União Soviética. Em Angola, por exemplo, de acordo com a política que visava neutralizar a expansão e frear a penetração da União Soviética em solo africano, a China apoiava a "Frente Nacional de Libertação", ao invés de entrar em contato com outros movimentos nacionalistas angolanos, em posição de rivais por serem aliados dos soviéticos ${ }^{9}$.

A Conferência Afro-Asiática de 1955, realizada em Bandung, na Indonésia, apresentara o significado histórico de oferecer oportunidades de contatos diretos entre a China e os países da África. Após a conferência, a China intensificou os contatos com os países africanos e os resultados foram animadores; desde então, os países africanos que estabeleceram relações diplomáticas com a China foram cada vez mais numerosos. As visitas de Zhou Enlai à África, durante a primeira metade dos anos 60 , fortaleceram ainda mais o entendimento mútuo entre as duas partes ${ }^{10}$. Entre 1960 e 1969, 14 países africanos estabeleceram relações diplomáticas com a China. No final de 1969, dos 41 países africanos independentes, 19 mantinham relações diplomáticas com a China, contra cinco nos anos $50^{11}$.

Nos anos de 1970 observou-se o fortalecimento das relações políticas sino-africanas, quando a China volta a ocupar seu lugar legítimo nas Nações Unidas em 1971, e melhora suas relações com os países ocidentais. Nas décadas anteriores, outro motivo da política chinesa na África era a retomada do seu lugar legítimo nas Nações Unidas e a expulsão do representante de Taiwan; assim, o país asiático buscara conter o reconhecimento de Taiwan como representante da China, com votos contra suas credenciais nas Nações Unidas. A redução do isolamento político imprimiu vigoroso impulso às relações com a África; até o final de 1979, o número de países africanos que estabeleceram e mantiveram relações diplomáticas com a China atingiu 44.

\footnotetext{
${ }^{9}$ MELVILLE, Chris; OWEN, Olly. "China and Africa: a new era of 'south-south cooperation"', Open Democracy, 07.07.2005, disponível em Acessível em http://www.opendemocracy.com/.

${ }^{10}$ Entre dezembro de 1963 e fevereiro de 1964, Zhou Enlai visita dez nações africanas.

${ }^{11}$ HONG-MING, Zhang. "A Política Chinesa na África”. In: BELLUCCI, Beluce (org.). "Abrindo os olhos para a China". Rio de Janeiro: EDUCAM, UCAM, 2004, pp. 233-196.
} 
Embora o governo chinês tenha dado especial importância as suas relações de cooperação econômica com os países africanos e elas terem se ampliado rapidamente, o principal interesse da China na África continuava sendo no campo político, com o tema da economia relegado ao segundo plano. Ao mesmo tempo em que apoiava a independência de países africanos, a China investia em projetos de infra-estrutura nos mesmos, porém, sem muita ligação com o desenvolvimento econômico. Ainda que, na época, em muitos Estados africanos havia uma visão predominantemente utilitária e pragmática das relações com a "grande China", preferindo auferirem dos benefícios económicos relativos ao reconhecimento político de Taiwan como um Estado independente da República Popular da China, o comércio entre a China e África atingiu o valor de 817 milhões de dólares no ano de 1977.

Nas décadas de 1970 e 1980, a China proveu países do continente africano com conhecimentos técnicos e relativos à medicina, bolsas de estudo e várias formas de ajuda, mas seu envolvimento no continente não era capaz de competir com os programas homólogos vindos do Ocidente. Durante a década de 1980, a África não ocupava um lugar muito importante nas preocupações internacionais de Beijing, que se concentrava em sua política interna de edificação econômica. No entanto, verifica-se a reorientação da estratégia internacional chinesa no período, optando por uma diplomacia a serviço da economia, despolitizando as relações sino-africanas numa época em que os intercâmbios comerciais e a cooperação econômica passavam a ser priorizados. Nos anos oitenta, quando as duas superpotências da Guerra Fria iniciaram um processo de retirada do continente e os países europeus reduziram quase para metade o volume da sua ajuda financeira, Beijing manteve os seus contatos locais e a sua ajuda ${ }^{12}$. No período, em que as relações com Angola e Moçambique observaram relativa melhora, o número de países africanos que reconheceram a China continuou crescendo: no final da década, dos 51 países africanos independentes, 47 mantinham relações diplomáticas com a China. A partir dos anos de 1990, com o desmoronamento de uma estrutura bipolar e o soerguimento chinês, a África ganha cada vez maior lugar de destaque para a China, como importante fonte de matérias-

\footnotetext{
12 “China's trade safari in Africa” Le Monde Diplomatique, May 2005.
} 
primas e mercado de produtos, acompanhando a intensificação das relações econômicas.

No plano político, a África, com seus atuais 53 países, continua sendo um campo de atividade importante da diplomacia chinesa, principalmente os que mantêm relações diplomáticas com a China e que lhe fornecem campos de atividade suplementares. As autoridades chinesas têm plena consciência da importância do continente africano: se o desenvolvimento da economia chinesa constitui um dos meios para alcançar posição de grande potência, os recursos políticos e econômicos africanos podem facilitar, em certa medida, a obtenção desse meio. A partir dos anos de 1990, com o desenvolvimento gradual da economia, um dos pontos essenciais da política diplomática da China continuou sendo a tentativa de melhorar sua posição e influência internacionais, e na sua política com a África a emergente potência também visou sempre desenvolver atividades a nível mundial com a participação dos países africanos.

O estreitamento das relações entre China e África, a partir dos anos de 1990, é marcado pela na multiplicação das consultas de alto nível entre os dirigentes dos dois lados, num contexto de deterioração das relações entre a China e os países ocidentais, que Ihe impunham sanções econômicas, o que estimulou o desenvolvimento das relações com os países em desenvolvimento, para objetivos de diverificação. Em 1993, o Ministério do Comércio Exterior e da Cooperação Econômica chinês elaborou um plano relativo à exploração do mercado africano e ao estreitamento da cooperação econômico-comercial sinoafricana, com objetivos de estimular as empresas chinesas a participarem do comércio com a África e a aumentarem o montante dos investimentos e a parte de mercado da China na África. Em 1996, para melhor assessorar as empresas chinesas instaladas na África, o governo chinês criou os Centros para o Investimento e o Comércio em dez países da África. No ano seguinte, o referido Ministério convocou a primeira conferência nacional sobre a cooperação econômica e comercial com a África. Com a implantação crescente de empresas chinesas na África, para facilitar o estabelecimento de contatos diretos entre as empresas chinesas e africanas, a partir do segundo semestre 
de 1998, passou-se a organizar duas vezes por ano, durante dois meses, o Seminário Sino-Africano dos Funcionários de Gestão Econômica.

Em janeiro de 2006, a China divulgou o seu primeiro documento de "Política para a África", pelo qual o governo chinês pretende incrementar a solidariedade e a cooperação com os países africanos em diversas áreas, mostrando ao mundo os objetivos da política africana chinesa, as medidas para alcançá-los e suas propostas de cooperação em várias áreas nos anos seguintes $^{13}$. $\mathrm{Na}$ área política, ressaltam-se os pontos das consultas de alto nível e dos intercâmbios entre setores legislativos, partidos políticos e governantes locais; enquanto que comércio, investimento, finanças, agricultura, infra-estrutura, recursos, ajuda econômica, alívio de dívidas e cooperação em fóruns multilaterais são temas da arena econômica. Educação, ciência, cultura, saúse, aspectos sociais, juntamente com paz e segurança completam os domínios de uma cooperação que segue o princípio do desenvolvimento comum. A partir da grande ênfase conferida ao intercâmbio comercial e econômico entre China e África, seus formuladores apostam no alargamento do estágio de cooperação verificado.

O marco de uma nova era nas relações sino-africanas em geral está na formação do Fórum de Cooperação entre a China e a África - FOCAC, em outubro de 2000, sob o princípio de "consultas de igualdade, aumento da compreensão, expansão dos consensos, fortalecimento da amizade e promoção da cooperação", a fim de enfrentar desafios do novo século. Do evento, que ocorreu em Beijing, participaram mais de 80 ministros da China e de 44 países africanos, e representantes de 17 organizações regionais e internacionais. $\mathrm{Na}$ reunião entre ministros dos Negócios Estrangeiros, antecedente ao referido encontro, tinham sido acordadas medidas de perdão redução ou anulação - da dívida dos países africanos, no montante de no montante de 1,2 bilhão de dólares, o fim de barreiras alfandegárias às importações da África, o reforço da cooperação técnica e o aumento da parte da África na assistência externa chinesa. Os dois documentos adotados

\footnotetext{
13 "China's African Policy". Ministry of Foreign Affairs from the People's Republic of China, 12.01.2006, disponível em http://www.mfa.gov.cn/
} 
durante o evento - a "Declaração de Beijing do Fórum sobre a Cooperação Sino-Africana" e o "Programa de Cooperação Sino-Africana em Matéria de Desenvolvimento Econômico e Social" - definem a orientação do desenvolvimento para as relações estáveis de uma parceria em longo prazo, oferecendo vantagens recíprocas no século XXI.

A segunda reunião ocorreu em Addis Ababa, capital da Etiópia, em dezembro de 2003. O "Plano de Ação de Addis Ababa (2004-2006)" foi documento-chave da conferência, que atraiu mais de 70 ministros da China e de 44 países africanos. A maior atenção em relação à África foi reforçada com a FOCAC de novembro de 2006, que reuniu 48 líderes e representantes das 53 nações africanas em Beijing. $O$ encontro, que celebrou 50 anos de relações diplomáticas entre chineses e africanos, contemplou a celebração de acordos de comércio e investimento entre autoridades de diversos países africanos com a China. No evento, que atraiu mais de 2.000 delegados e empresários chineses, foram assinados 16 acordos comerciais e de investimentos, e o presidente chinês, Hu Jintao, anunciou um conjunto de medidas para ampliar todo o espectro de relações entre China e África, que cobriam relações políticas, econômicas, tecnológicas, sociais e culturais, visando criar uma situação em que ambas as partes obteriam ganhos.

Assim, a marcante reunião aprovou um plano para promover um "novo tipo de parceria estratégica" baseada em cooperação pragmática, igualdade e benefício mútuo, por meio do qual a China se comprometeu a duplicar a ajuda à África até o ano de 2009, num valor que chega próximo de 1 bilhão de dólares; a estabelecer um fundo de desenvolvimento sino-africano de cinco bilhões de dólares para encorajar empresas chinesas a investirem na África, a prover as somas de três bilhões em empréstimos preferenciais e de dois em créditos especiais a países africanos; a cancelar todas as dívidas provenientes de empréstimos livres de juros do governo chinês que venceram ao final de 2005 para os 31 países menos desenvolvidos e mais endividados da África que mantêm relações com a China, num valor estimado em 1,4 bilhões de dólares; a promover uma maior abertura do mercado chinês às exportações dos países africanos menos desenvolvidos aumentando o número de produtos que recebem tratamento tarifário nulo de 190 para 440; a oferecer treinamento a 
15.000 profissionais africanos, duplicar o número de bolsas do governo concedidas anualmente (para 4.000) e enviar 100 especialistas em agricultura e 300 voluntários jovens ao solo africano; e a construir 30 hospitais, 30 centros de tratamento contra a malária e 100 escolas rurais ${ }^{14}$.

Partindo para a evolução do relacionamento entre o gigante asiático e os países africanos lusófonos, considera-se o lançamento do Fórum para a Cooperação Econômica e Comercial entre a China e os Países de Língua Portuguesa como fato de muita significância para seus países membros, como mecanismo a desenvolver os laços entre os mesmos. Macau, sede do Secretariado Permanente, serve de plataforma de ligação da China com os países lusófonos. Desde a sua criação, em 2003, o Fórum tem desempenhado um papel importante nas áreas do comércio, investimento, tecnologias e recursos humanos, obtendo êxitos positivos. No primeiro encontro, as partes saudaram o nível de cooperação encontrado e mostraram-se convictas da existência de grandes potencialidades para o seu desenvolvimento, concordando com o estabelecimento de relações de parcerias no plano da cooperação econômica e comercial, assentes nos princípios da confiança mútua, da igualdade, da reciprocidade e da complementaridade de vantagens, da diversificação das formas de cooperação e da partilha de interesses. A primeira conferência ministerial destacou objetivos de fomento nas áreas intergovernamental, comercial e empresarial, assim como anunciou metas de reforço da cooperação nos temas da agricultura, da pesca, da engenharia e das infra-estruturas, e dos recursos naturais e humanos ${ }^{15}$.

A segundo fórum ocorreu em 2006, resultando em um "Plano de Ação" com objetivos para o período de 2007 a 2009. O documento ressalta a determinação das partes em promover e dinamizar parcerias efetivas de cooperação com fins de concretizar o desenvolvimento comum, alargando as áreas da estratégia cooperativa. Cada área é tratada de modo mais específico no tocante às medidas a ser tomadas para alcançar os objetivos acordados.

\footnotetext{
14 "Forum on China-Africa Cooperation-Beijing Action Plan(2007-2009)", Council on Foreign Relations, 16.11.2006, disponível em http://www.cfr.com/.

15 "Conferência Ministerial de 2003 - Plano de Ação para a Cooperação Econômica e Comercial", 13.10.2003, acessível em www.forumchinaplp.org
} 
Em relação às atividades comerciais, a partir do reconhecimento do crescente volume de trocas, as partes acordaram em seguir mecanismos do livre comércio para aumentá-las para um valor entre 45 e 50 bilhões de dólares, com preferência para as exportações dos países africanos para a China. Quanto aos investimentos, busca-se sua duplicação nos dois sentidos, sendo que $\mathrm{o}$ incentivo à sua captação seria reforçado com a divulgação das legislações que tratam do tema em cada um dos países. A estratégia de cooperação entre empresas é alargada para os vários domínios de atividade econômica, tais como as áreas das infra-estruturas, transportes, telecomunicações, energia, agricultura e aproveitamento dos recursos naturais, indo além da promoção de melhores climas de investimentos e da exploração de projetos de interesse comum, que contribuam para o desenvolvimento local, conforme o documento de 2003.

A importância que o desenvolvimento dos recursos humanos e a criação de empregos representam para o desenvolvimento econômico e social dos países participantes é levada em conta para a promoção de ações de formação, com áreas prioritárias definidas de acordo com as especificidades de cada país do Fórum. A cooperação para o desenvolvimento é reforçada com as decisões de concessão de empréstimos e linhas de crédito aos países africanos pela China, assim comoa medida de anulação das dívidas relativas aos créditos sem juros, ainda não reembolsados, e cujo prazo se expirou até finais de 2004. Enfim, as áreas do turismo, da ciência e da tecnologia e da cultura complementam um novo estágio cooperativo entre as partes ${ }^{16}$.

As motivações para a criação dos fóruns discutidos estão no incremento das reformas econômicas na China, de modo a participar plenamente da cooperação econômica mundial, rumo tomado para o alcance de melhores níveis de desenvolvimento econômico. Os países de língua portuguesa, que em sua totalidade se espalham pelos quatro cantos do mundo, não só apresentam grandes reservas de recursos naturais e constituem um mercado de consumo com mais de 200 milhões de pessoas, como também, devido à

\footnotetext{
16 "Plano de Ação para a Cooperação Econômica e Comercial (2007-2009) - Segunda Conferência Ministerial", setembro de 2006, acessível em www.forumchinaplp.org
} 
sua posição geográfica privilegiada, apresentam uma boa complementaridade para os objetivos de desenvolvimento econômico da China. Angola e Moçambique, ricos em recursos naturais e energéticos, representam excelentes chances para o desenvolvimento de negócios lucrativos com 0 estabelecimento de parcerias em economia e comércio, enquanto que, se combinados a Cabo Verde, Guiné-Bissau e São Tomé e Príncipe, completam um quadro de localidades estratégicas para o fomento da cooperação em setores diversos.

Ambas as partes saúdam a nova dinâmica nas relações de cooperação, quando ocorre maior abertura a produtos de exportação nos mercados chinês e africano, e observa-se muito apoio a empresários da China desejosos de investir nas oportunidades da África. Esperam-se impactos positivos da oferta chinesa de materiais de boa qualidade a preços competitivos para os países africanos na corrente de comércio bilateral, especialmente para os países da CPLP, que têm aumentado as suas importações provenientes da China nos últimos anos. Às vésperas da segunda Conferência Ministerial do Fórum de Cooperação entre a China e a comunidade losófona, o secretário-geral Wang Chen An revelara que o as trocas comerciais em 2005 tinham chegado a 23 bilhões de dólares, representando um aumento de 26,9\% em relação a 2004. No ano seguinte, em 2006, o comércio atingiu quase 35 bilhões, mais $51 \%$ do que no ano anterior. Até o presente momento, esta porcentagem tem aumentado de ano para ano, sendo que, de acordo com estimativas traçadas no encontro, as partes buscarão aumentar significativamente o patamar de comércio bilateral e de investimentos.

Em janeiro de 2008, as trocas comerciais atingiram 46,8 bilhões de dólares, um aumento de $65,5 \%$ comparativamente ao período homólogo de 2007 , sendo que o incremento foi verificado tanto nas exportações do conjunto dos lusófonos africanos para a China quanto nas importações nestes países, de acordo com as estatísticas alfandegárias chinesas Os Ministros do Fórum para a Cooperação Econômica e Comercial entre a China e os Países de Língua Portuguesa agendaram a terceira conferência para 2009. 


\section{RELAÇÕES COM ANGOLA E MOÇAMBIQUE}

Angola e Moçambique são países que ganham destaque na análise do incremento cooperativo entre China e os países africanos de língua portuguesa pelo fato de apresentarem laços históricos e atuais mais fortes com o gigante asiático, em comparação aos outros três países, Cabo Verde, Guiné-Bissau e São Tomé e Príncipe, tratados em parte posterior. A estratégia chinesa de cooperação tripartite, nomeadamente nas áreas do comércio, dos investimentos e da ajuda, tem sido mais marcante nos dois países selecionados.

O primeiro deles tem como principal razão do forte envolvimento chinês o petróleo, num setor em que a atuação do dragão em comércio, investimentos e ajuda se complementam. Angola é, em termos reais e potenciais, um dos países mais ricos da África, devido às suas abundantes reservas de petróleo, às amplas capacidades de geração de enegia hidroelétrica, aos vários tipos de minerais e à grande extensão de sua terra fértil, da qual apenas uma pequena parte é explorada. A recente incursão chinesa, fortemente notável nos vários tipos de atividades econômicas que se processam em Angola, chama muito a atenção a níveis nacional e global, gerando debates em torno das possíveis conseqüências.

Ao dragão interessa a comercialização e o investimento em recursos energéticos, para sustentar uma economia de grande crescimento; no entanto, é importante perceber que a atuação da China em Angola não se restringe à area de petróleo e recursos naturais, mas se estende aos investimentos em infra-estrutura, com projetos de construção de escolas, hospitais, estradas e moradias. Angola é um dos países que fazem parte da "África em desenvolvimento", que desfruta de seu melhor período de expansão econômica sustentável desde o fim do período colonial, e verifica-se que o atual crescimento é impulsionado pelos maciços investimentos provenientes da cooperação com a China.

Com relação a Moçambique, também nota-se o incremento cooperativo nas áreas do comércio e dos investimentos, sendo que a agricultura as infra- 
estrutura correspondem aos setores de destaque nas relações com a China. A cooperação entre os dois países, que remonta ao apoio que Beijing concedeu na luta armada contra a dominação colonial portuguesa, assim como ocorrera em Angola, traduz-se em ações de cooperação econômica e comercial em áreas como a agricultura, indústria de mineração, construção de infraestruturas e formação de recursos humanos. Discute-se o potencial energético do país africano, e as possibilidades de estender a cooperação a novas áreas.

Analisa-se a ligação entre comércio, investimentos e ajuda e o alcance do desenvolvimento, as ocorrências que favorecem tal movimento e os caminhos a percorrer por Angola e Moçambique. Nisso se verificam as reformas ocorridas, e os planos passados e atuais para sua implementação, em seguimento ao objetivo de se auferir benefícios em termos econômicos e sociais da cooperação com a China. O papel do Estado na dinamização das áreas sócio-econômicas e na criação de um bom ambiente de negócios favorável à iniciativa privada e ao investimento externo é fundamental para os almejados resultados. A partir dos fóruns sino-africanos, as partes concordaram em esforços de implementação desses resultados, no âmbito do impulsionamento de novo tipo de relações de parceria estratégica entre a China e a África, que tem foco na prosperidade conjunta. 


\section{China e Angola: energia e crescimento}

A Angola apresenta-se como um dos países de destaque no continente africano no contexto da estratégia chinesa. O país, que é rico em petróleo e recursos minerais, está entre as nações africanas que mais crescem no planeta. A expansão de seu Produto Interno Bruto foi de $23 \%$ em $2007^{17}$. O petróleo é o principal fator do envolvimento chinês no continente africano em geral nos tempos recentes, em que o gigante asiático busca fontes de recursos naturais e energéticos para sustentar sua emergente economia. As reservas de petróleo do continente africano representam $7 \%$ do volume total do mundo, e a e a produção atual, de 6 milhões de barris ao dia, deve dobrar nas próximas duas décadas. Angola atrai empreendimentos chineses por ser um dos maiores produtores da importante fonte energética, mas também por apresentar um mercado consumidor potencial de grandes expectativas num país em desenvolvimento.

Angola aprofunda laços comerciais com a China, e posiciona-se em posição de primeiro lugar entre os parceiros comerciais do país asiático na África. Boa parte da rápida expansão de Angola se deve à estratégia comercial com a China, pois o lucro com as exportações representa o motor do processo de reconstrução angolano, cinco anos após o fim da guerra civil que matou aproximadamente 500 mil pessoas e arrasou a infra-estrutura local. Os investimentos chineses, em bilhões de dólares vindos de grandes petrolíferas, ajudam a levantar um país que hoje é considerado parte da "África que está dando certo". Em Luanda, os canteiros de obras apresentam-se cheios de operários chineses, cidadãos em relação aos quais se estima uma presença em milhares em todo o país ${ }^{18}$.

Apesar dos impressionantes laços atuais entre os dois países, o histórico das relações bilaterais apresentou períodos de estagnação e volatilidade. Quando ainda era colônia de Portugal, a China provia assistência

\footnotetext{
17 “Angola vive milagre econômico” O Estado de São Paulo, 17/12/2007

${ }^{18}$ KANINDA, John. "O salto gigante de Angola no palco da economia mundial". Business Day, Dezembro 2005.
} 
e treinamento a um dos movimentos de libertação nacional de Angola, a União Nacional para a Independência Total de Angola (UNITA), rival dos apoiados pelos Estados Unidos, o FNLA (Frente Nacional de Libertação de Angola), e pela União Soviética, o MPLA (Movimento Popular de Libertação de Angola), que governou logo após a Independência, alcançada em novembro de $1975^{19}$. Os dois países só estabeleceram relações diplomáticas em 1983, a partir de quando se segue um período de quase duas décadas em que a China, mais fechada ao exterior por conferir preferencialmente esforços desenvolvimentistas em seu próprio território, fornece assistência em pequena escala ao país, com destaque para as atividades de pesca, habitação e elétricos. Em vista do que se veria na futura cooperação, no século $X X I$, o papel chinês foi bem modesto.

A economia angolana observou um forte crescimento nos anos anteriores à independência (1960-1974), com um PIB médio anual de 7,8\%. Em 1973, o petróleo tornara-se o principal produto de exportação, ultrapassando o café; na época, o país era um dos quatro maiores produtores mundiais de diamante e um grande produtor de minério de ferro, assim como também exportava produtos agrícolas e apresentava quase auto-suficiência na indústria alimentícia. A indústria manufatureira, apesar de pequena, expandiase na década de 1960 e início da de 1970, a partir de condições como crescimento do mercado, políticas de proteção e incentivos de investimento. No entanto, após 1975, a infra-estrutura produtiva foi prejudicada com o êxodo de 90\% das pessoas envolvidas nas arenas técnica, de administração pública e dos negócios, o que resultou numa década de retrocessos, em que a tomada de medidas econômicas inadequadas, no âmbito do planificação, somaram-se aos efeitos da guerra do período pós- independência.

Nos anos iniciais do século XXI, verificou-se que o estado da economia de Angola era resultado de um conjunto de fatores, entre os quais ganham destaque a guerra civil, as distorções econômicas e o mal emprego dos recursos financeiros. As tentativas de recuperação econômica, com metas de

\footnotetext{
19 "História Cronológica da Guerra e Paz em Angola". Angola Digital, disponível em http://www.angoladigital.net/.
} 
estabilidade macroeconômica, ajuste estrutural, distribuição igualitária de recursos, ajuste estrutural e redução da pobreza, muitas vezes foram frustradas pela falta de níveis adequados de poupança, ajuda estrangeira e linhas de crédito. A partir de 1987, o país buscou realizar reformas voltadas ao estabelecimento de uma economia de mercado, a ser alcançada com a redução da interferência estatal, a mobilização racional da renda proveniente das exportações, a diversificação das atividades econômicas, a reconstrução de sua infra-estrutura básica, e a melhoria da educação nos sentidos acadêmico e profissional. A partir da década de 1990, o governo aprovara legislações e programas para a melhoria do ambiente econômico, entre os quais o Programa de Privatização das Companhias Estatais, amparado pelos decretos 32/89 e 8-F/90 e aprimorado pela lei No. 10/94 $4^{20}$, a criação do Instituto de Investimento Estrangeiro, a partir do estabelecimento da lei No.15/94 ${ }^{21}$.

O governo seguiu com novos pacotes de medidas para o fortalecimento de sua economia, com a redefinição da política de salários e das regras para a atividade bancária, a revisão e atualização das tarifas aduaneiras, e o ajuste do sistema de preços, no âmbito do "Programa de Políticas Econômicas e Sociais de 1997". Mas percebia-se que a evolução da situação econômica de Angola dependia da estabilidade política e militar, ainda ausentes no país. Paz e segurança para os cidadãos, juntamente com o funcionamento normal das instituições do Estado, criariam as condições necessárias para a recuperação e o desenvolvimento almejados e que vêm sendo alcançados nos últimos anos ${ }^{22}$. Após o alcance de estabilidade, o país passou a atrair muitos investimentos estrangeiros, especialmente da China, em busca dos abundantes recursos naturais presentes em Angola. O nível atual pôde ser alcançado após a morte

\footnotetext{
${ }^{20}$ Os decretos permitiram que as empresas estatais fossem transferidas ao setor privado ou que adotassem meios de se associarem às companhias privadas.

21 A lei modifica a legislação existente de investimento estrangeiro, conferindo grande importância à promoção de uma política neste sentido, sem desvinculá-la da situação econômica enfrentada pelo país. O Instituto é estabelecido como serviço público intermediário do investidor estrangeiro.

22 "As Perspectivas Econômicas de Angola depois da Paz". Angola Digital, 12.01.2006, disponível em http://www.angoladigital.net/.
} 
do líder da UNITA, Jonas Savimbi, em fevereiro de 2002, e a assinatura de acordos de paz com o governo, com probabilidades de longa duração.

Ainda no início deste século $X X I$, eram muitos os desafios para uma economia com desequilíbrios em suas contas internas e externas e para uma estrutura produtiva destruída. O investimento externo assumiu uma inegável importância na regeneração de Angola, e o destaque é conferido à China, potência emergente do Leste Asiático que tem se estabelecido fortemente no país africano por meio da atividade, mas cuja atuação não se resume à mesma. As relações entre China e Angola chegaram a um novo patamar em março de 2004, quando o Eximbank (Banco de Importação e Exportação da China) ofereceu 2,4 bilhões de dólares em empréstimo com garantias em petróleo a Angola, em termos favoráveis, para a reconstrução do país ${ }^{23}$.

As atuais altas taxas de crescimento econômico alcançadas pelo país se devem ao setor petroleiro, que apresenta crescente produção e preços recordes. A produção de petróleo e suas atividades complementares contribuem para aproximadamente $85 \%$ do PIB de Angola, de acordo com dados da Central de Inteligência Americana (CIA). Além dos ganhos provenientes da exportação de petróleo, também promoveu um melhor ambiente econômico a implementação, pelo Banco Central, de um programa de estabilização cambial que comprava Kwanzas, a moeda local, fora de circulação, utilizando reservas estrangeiras, o que contribuiu para a reduções significativas da inflação ${ }^{24}$.

No ano de 2004, Angola tornou-se o maior mercado fornecedor de petróleo para a China entre os países africanos, passando à posição de terceiro lugar a nível global, depois de Arábia Saudita e Irã. Ainda nos anos de guerra civil, as principais companhias petrolíferas chinesas estabeleceram boas relações com a empresa local Sonagol, sem interromper suas operações na costa oeste africana. Além de adquirir equidade nas concessões de exploração de petróleo, com a formação do consórcio Sinopec-Sonagol, os chineses

23 "China In Angola. An Emerging Energy Partnership". The Jamestown Foundation, 13.11.2006, disponível em http://www.jamestown.org/.

${ }^{24}$ CIA. The World Factbook 2008. Central Intelligence Agency, March 2008. 
também têm investido pesadamente na infra-estrutura de processamento de petróleo. Os lucros da parceria têm alcançado níveis recorde, e estima-se a continuidade de bons resultados quando se leva em conta as muitas fontes ainda inexploradas no país. A partir disso, e estendendo a riqueza angolana em outros recursos naturais, espera-se que a importância do país para a insaciável demanda chinesa por matérias-primas aumente ainda mais.

A visita do vice-presidente da China, Zeng Peiyan, a Angola, em fevereiro de 2005, conferiu vigoroso impulso à cooperação. Segundo o representante chinês, em declaração à imprensa, o acontecimento permitiu consolidar a "amizade tradicional, tradicional, aprofundar o conhecimento mútuo e promover a cooperação com benefícios mútuos". Na sequência dessa visita, Angola e China assinaram nove acordos de cooperação, sendo cinco governamentais e quatro empresariais, com destaque para o protocolo no domínio dos recursos energéticos, minerais e infra-estruturas e um acordo de cooperação econômica e técnica ${ }^{25}$. Entre a Sinopec e a Sonagol foram rubricados um acordo de fornecimento de petróleo e um memorando sobre estudos de exploração petrolífera. Também se destaca contrato da rede telefônica entre as empresas ZTE, chinesa, e a angolana Mundo-Startel. Um empréstimo de 6,3 bilhões de dólares e um compromisso de investir US $\$ 400$ milhões no setor de telecomunicações e US $\$ \$ 100$ milhões para a modernização da rede de comunicações militares de Angola completam os resultados da importante visita.

O estreitamento de laços é ressaltado pelo fato de Angola ter ultrapassado a Arábia Saudita em fevereiro de 2006, tornando-se o principal exportador de petróleo para a China, contabilizando 456 mil barris por dia, o que respondeu por $15 \%$ do total das importações chinesas de petróleo. Entre janeiro e março de 2008, as exportações angolanas alcançaram 688 mil barris diários, totalizando 8,48 milhões de toneladas, segundo dados da Administração Geral de Alfândegas da China. Em 2007, Angola exportou para a China 25 milhões de toneladas, $10 \%$ a mais do que em 2006. Caso o

\footnotetext{
25 "Governante chinês considera bem sucedida visita a Angola". Jornal de Angola, 27/02/2005.
} 
crescimento se mantenha, estima-se que as exportações angolanas podem chegar a 34 milhões de toneladas até o final do $a^{26}{ }^{26}$.

A parceria comercial tem evoluído positivamente na primeira década do século XXI, período em que Angola desfruta de altas taxas de crescimento econômico. A China tornou-se o principal destino das exportações em 2006, com $41,3 \%$, enquanto que correspondeu por $8,9 \%$ das importações angolanas, em posição de quarto lugar atrás de Estados Unidos, Portugal e Coréia do Sul. No referido ano, em junho, o primeiro-ministro chinês Wen Jiabao realizou uma visita a Angola, como parte de um roteiro por sete nações africanas. Em seguimento à Política Africana da China, Wen disse que "o desenvolvimento das relações sino-angolanas corresponde aos interesses fundamentais dos dois povos e dos dois países, para o alcance da cooperação bilateral nos diversos domínios" ${ }^{\prime 2}$. Por sua parte, o premiê angolano, Fernando Dias dos Santos, que afirmara, no encontro com Jiabao, que "a China precisa de recursos naturais e Angola, de desenvolvimento, por isso podem estabelecer uma cooperação construtiva em domínios estratégicos", visitou a China em outubro de 2006, com vistas a tratar de cooperação em transportes aéreos, pesca, telecomunicações e obras públicas.

A abertura de um consulado angolano em Macau, em novembro de 2007, resulta da criação do Secretariado Permanante do Fórum para a Cooperação Econômica e Comercial entre a China e os Países de Língua Portuguesa. Ademais de se levar em conta as ligações históricas entre Macau e Angola, que já estiveram sob o domínio colonial português, o feito consolida o interesse do país africano de cativar os interesse dos empresários da importante centro chinês. O estabelecimento ds Câmara de Comércio das Companhias Chinesas em Angola, em março de 2006, já indicava a crescente presença dos negócios chineses no país africano, sendo que o grosso dos projetos chineses tem se dedicado à reabilitação da infra-estrutura nele presente, e correspondendo à estratégia do governo angolano de dar

\footnotetext{
26 "Angola atinge primeiro lugar no fornecimento de crude à China". Portal das Empresas Governo de Angola, 20.04.2008, disponível em http://www.angolainternet.ao/.

27 "Crescimento econômico chinês define agenda proativa para a África". Conselho Empresarial Brasil-China, 08.08.2006, disponível em http://www.cebc.org.br/.
} 
prioridade à reabertura das vias de transporte devastadas pelos 27 anos de guerra civil.

Assim, a parceria entre Angola e China vai além das atividades relacionadas ao petróleo e incorpora projetos diversos, especialmente na melhoria da precária infra-estrutura presente no país africano. Ainda em junho de 2006, o governo do China concedeu a Angola, por meio do Eximbank, um crédito de US\$ 2 bilhões para o programa angolano de reconstrução e desenvolvimento nacional. Empreendimentos chineses são verificados na construção de escolas, clínicas, hospitais, moradias, e estradas. Entre as obras de recuperação da infra-estrutura, destaca-se a reabilitação da principal via ferroviária de Angola, "Caminhos de Ferro de Benguela", quase totalmente desativada durante o conflito armado que se seguiu à independência do país em 1975, e inviável para projetos de reabilitação pela situação de insegurança então prevalescente ao longo da linha, que liga o porto de Lobito no Oceano Atlântico ao vizinho República Democrática do Congo. Outros projetos incluem um novo aeroporto e uma estrada de ligação entre Luanda e a cidade de Malange, no interior do país.

Em 2006, a China ultrapassa Portugal, Rússia e Brasil como principal fornecedor de ajuda a Angola, onde se verifica a utilização dos recursos para reconstrução e desenvolvimento. Mesmo diante da ausência de fontes oficiais que contabilizem com exatidão o número de chineses vivendo em Angola, estima-se que a comunidade chegue a milhares, entre 10.000 e 80.000. A participação crescente chinesa na economia de Angola, onde muitos chineses vivem e trabalham, pode significar uma maior habilidade de influenciar as políticas de Angola. Apesar da magnitude dos projetos chineses no país, pouco é conhecido sobre os mesmos, e não há clareza sobre quanto dinheiro total é fornecido na forma de empréstimos e ajuda por Beijing, uma quantia que deve variar entre US\$ 2 bilhões a US\$ 9 bilhões. A falta de transparência nas atividades é reforçada com a incapacidade de se identificar quantas companhias angolanas têm recebido contratos sob os empréstimos do Eximbank, sendo que, pelos termos do contrato, 30\% devem ser destinados 
àquele país ${ }^{28}$. Também seria necessário acessar quantos cidadãos angolanos são empregados pelos chineses, no sentido de se verificar os benefícios de uma estratégia que se denomina cooperativa.

Críticos de uma suposta "invasão chinesa" apontam para o fato de os chineses tomarem os empregos e contratos de pessoas e empresas angolanas, reclamam da não ocorrência de transferência de tecnologia com o estabelecimento dos projetos, e ainda questionam a qualidade dos bens e serviços recebidos da China. Há uma percepção de que os chineses ficaram com a maior parte dos empréstimos e trouxeram um grande número de trabalhadores chineses para operar projetos no país africano. A nível internacional, as preocupações em relação à estratégia chinesa para Angola se verificam na vantagem competitiva que as empresas petrolíferas do gigante asiático possuem devido às linhas de crédito e outros incentivos oferecidos pelo governo chinês e suas agências. Há o temor de que a injeção de dinheiro chinês diminua a influência do Fundo Monetário Internacional (FMI) e de outros atores, principalmente países ocidentais, na promoção de comércio, reformas econômicas e liberalização em Angola. Empresas portuguesas, por exemplo, que tradicionalmente dominavam o mercado do país, são deixadas para trás por suas contrapartes orientais.

Antes de de olhar para a fortalecida parceria como ameaça aos interesses do Ocidente, deve-se atentar para o fato de Angola não ter na China seu único ou mais importante parceiro entre todos. Desde que a segurança energética se tornou uma preocupação constante para a China, o país entrou numa estratégia de reforço de sua influência e presença em Angola. De fato, a corrente de comércio bilateral com a China e o fluxo de investimentos e ajuda recebidos têm aumentado consideravelmente, mas os angolanos desejam continuar recebendo bens, serviços e investimentos de outros países em setotes petrolíferos ou não. A maioria da população de Angola não teme nenhuma espécie de "colonização chinesa", na medida em que a cooperação com o país asiático é enquadrada nos grandes e necessários projetos. A parte

\footnotetext{
28 "Angola: China's African foothold". BBC News, 20.06.2006, disponível em http://news.bbc.co.uk/.
} 
chinesa espera que os angolanos insistam em maior qualidade e transferência de técnicas, assim como apóia que as companhias de petróleo forneçam treinamento à população do país africano e outsourcing às empresas angolanas.

O fato de Angola estar crescendo a "ritmo chinês" e recebendo grandes somas em dinheiro, e observar, ao memo tempo, uma gigantesca parte da população abaixo da linha da pobreza, em torno de $70 \%$, gera controvérsias quando da análise da situação do país e de suas perspectivas. O desemprego e o subemprego também afetam os angolanos, em uma percentagem que supera metade da população, e a concentração de renda vem aumentando. $O$ milagre econômico pode ser visto nas ruas de Luanda, que tem tido sua paisagem modificada, para uma de trânsito intenso, poluição, canteiros de obras e cartazes anunciando luxuosos empreendimentos imobiliários. Outras partes da cidade apresentam-se repletas de favelas, em meio a ocupação desordenada, saneamento precário e alastramento de doenças como a cólera. O governo de Angola espera utilizar os fluxos de investimento e ajuda econômica recebidos da China em projetos de reparo das infra-estruturas, o que inclui a reconstrução de estradas, pontes, escolas e hospitais em todo 0 território. Mas pode-se afirmar que ainda vai levar um tempo para que o país efetive o processo de transferir os benefícios da estratégia cooperativa com a China para sua população, que ainda sofre com a corrupção e a falta de transparência na administração do governo.

Analistas apontam para a falta de uma política que estimule a diversificação da economia como problema a ser superado pelas dirigências angolanas, de modo a reduzir sua dependência com o setor dos combustíveis, que dominam a pauta de comércio internacional do país. É de se notar que mais reformas precisam ser realizadas no setor de políticas macroeconômicas, para que o país africano consiga auferir da maneira mais eficiente dos benefícios da cooperação com a emergente potência asiática, que apresenta oportunidades de desenvolvimento num bom momento para o continente africano em geral, dentro do qual Angola ocupa lugar de destaque, pelos abundantes recursos naturais e pelo recente boom de crescimento econômico e reconstrução pós-guerra civil. 


\section{China e Moçambique: agricultura e infra-estruturas}

Moçambique também se insere no consolidado crescimento do interesse da República Popular da China em investir política e economicamente no continente africano, a partir das necessidades chinesas de matérias-primas e mercados. As relações com Moçambique datam da década de 1960, quando a República Popular da China conferia apoio ao movimento FRELIMO na luta por independência contra a metrópole portuguesa. A Frente de Libertação de Moçambique se formou pela união de três movimentos contrários à opressão colonial, e iniciou o movimento de libertação em 1964. O estabelecimento de relações diplomáticas se deu logo após a proclamação da independência nacional, em 25 de junho de 1975, na base das quais as partes vêm desenvolvendo uma cooperação que foi resistindo às mudanças operadas tanto na conjuntura internacional como na situação interna de cada país.

Após a independência, as relações bilaterais observaram uma fase de relativa limitação, tendo em vista a aproximação do governo com o lado soviético, no contexto da Guerra Fria. Adotou-se o modelo socialista para responder as demandas sociais imediatas e, a partir de 1977, a FRELIMO tornou-se um partido de orientação marxista-leninista. O novo governo independente guiou-se pelo controle e intervenção estatal nos setores econômicos e sociais, como modelo ideal para organizar o funcionamento da administração e garantir a produção e os mecanismos necessários para manter uma economia operacional. Com o fim da bipolaridade mundial, a China perdeu relativamente seu interesse no país do leste africano por focar-se em prioridades domésticas. No entanto, nos últimos anos, o envolvimento chinês em Moçambique deu um grande salto, em termos de comércio, investimentos e ajuda econômica, pilares da política africana da China que servem de referência neste trabalho. Comparativamente a outros países, como Angola, o engajamento do gigante asiático não é tão forte, mas sua presença em Moçambique tem sido considerável.

No momento de sua independência, Moçambique figurava entre as nações mais pobres do planeta, e sua situação tornou-se ainda pior com os 
anos de guerra civil que se seguiram de 1977 a 1992. As relações com a China, na década de 1980, eram modestamente reforçadas no âmbito da ajuda externa, a partir de quando equipes de médicos e especialistas agrícolas chineses começaram a trabalhar no país africano. A década, no entanto, marca a transição de uma economia centralmente planificada para uma economia aberta, de mercado. No início do período, o país apresentava, entre outros problemas, elevadas dívidas externas e internas, e havia a percepção da necessidade de mudanças no sentido da liberalização econômica, por meio de um programa de ajustamento estrutural, que envolvesse livre comércio, desregulamentação e privatização. Em 1987 e em 1990, pelos PRE (Programa de Reabilitação Econômica) e PRES (Programa de Reabilitação Econômica e Social), o governo adotou uma série de reformas macroeconômicas para estabilizar a economia, mas o momento político ainda carecia de uma transição democrática.

O FRELIMO abandona o marxismo em 1989, e uma nova Constituição, no ano seguinte, prepara o caminho para eleições multipardidárias, num processo de descentralização política e administrativa. Um acordo de paz negociado pelas Nações Unidas entre o partido dominante e o que the era contrário, o RENAMO (Resistência Nacional de Moçambique), cessou os conflitos em $1992^{29}$. As primeiras eleições presidenciais se deram em 1994, e uma importante conquista democrática é alcançada em 2004, quando o presidente Joaquim Chissano, que permanecera 18 anos no poder, é sucedido por Armando Guebuza, que promete dar continuidade às políticas econômicas de encorajamento aos investimentos externos diretos. Os passos tomados neste sentido, combinados com o recebimento de assistência e doações externas, num ambiente politicamente mais estável, levaram a melhorias nas taxas de crescimento observadas recentemente pelo país.

Ao longo das décadas de 1980 e 1990, Moçambique fundou as bases para que os parceiros comerciais externos tivessem motivos suficientes para

\footnotetext{
${ }^{29}$ CRAVINO, Janete. “Conflitos Internos - Resolução de Conflitos”. Revista Militar, 14.12.2005, disponível em http://www.revistamilitar.pt/.
} 
inspirarem uma grande confiança pelo país face à capacidade que as autoridades monetárias têm conseguido em manter volumes adequados de meios de pagamento sobre o exterior. O Estado, por meio da execução de adequadas políticas, como a orçamentária, tem regulado e dinamizado as áreas sócio-econômicas mais importantes, e criado um bom ambiente de negócios muito favorável ao desenvolvimento da iniciativa privada. As reformas jurídicas no âmbito da legislação financeira, fiscal, laboral, comercial e da terra realizadas pelo Governo contribuem significativamente para fortalecer esse bom ambiente com a respectiva atração do investimento privado nacional e externo, fato verificado nos dias atuais.

Moçambique tem observado fortes taxas de crescimento econômico desde o final da guerra civil, para as quais tem contribuído a reconstrução pósconflito. Reformas fiscais melhoraram a capacidade do governo na coleta de renda, nelas incluindo a reforma dos serviços aduaneiros. O favorecimento da iniciativa privada e da entrada de capital estrangeiro permitiu maior recuperação econômica, tornando o país mais confiável aos olhos dos principais credores e, desta forma, o governo tem conseguido novas linhas de crédito e a negociação da dívida. A inflação, reduzida ao final dos anos de 1990, e aumenta para dois dígitos no período de 2000-2006, foi novamente dimunuída para 8\% em 2007, enquanto que o crescimento do PIB chegou aos $7,5 \%$, depois de anos seguidos com taxas nestes níveis: 7,8\% em 2003, 7,2\% em 2004, 7,5\% em 2005 e $7,9 \%$ em $2006^{30}$.

A partir de uma melhor fase em economia e finanças, somada à estabilidade política, aumenta-se 0 interesse de países desenvolvidos e emergentes em auferir benefícios em comércio e investimentos. A China tem aumentado consideravelmente o comércio com Moçambique, especialmente nos últimos 4 anos. Em 2004, o comércio bilateral era de US\$ 70 milhões e, apenas dois anos depois, em 2006 alcançou US\$208 ${ }^{31}$ milhões. A triplicação deste valor significa que Moçambique apresentou um dos crescimentos mais

\footnotetext{
30 "Resumo Histórico". Portal do Governo de Moçambique, disponível em http://www.govnet.gov.mz/.

31 "Comércio com China atinge 208 milhões USD". Portal do Governo de Moçambique, 20.04.2007, disponível em http://www.govnet.gov.mz/.
} 
rápidos entre as nações africanas que têm reforçado laços comerciais com a China.

É importante ressaltar que as atividades comerciais, no caso da cooperação sino-moçambicana, diferentemente de outros países dos quais Angola é exemplo, não é centrada na importação de matérias-primas energéticas como petróleo e gás natural. O comércio é dominado pelas importações de produtos agrícolas, pescados e produtos derivados de florestas. Observa-se também a extensão dos investimentos na área dos serviços. Enquanto isso, as importações do país africano provenientes da China incluem maquinaria e bens manufaturados a baixos preços. Em 2006, a China figurava-se entre os principais mercados de exportação e importação de Moçambique, em quarto lugar com 3\% do total de exportações moçambicanas, e em terceiro entre os destinos da produção do país africano, com 5,4\%.

No contexto da lusofonia, em 2007, Moçambique fechou a lista dos principais parceiros chineses em termos de comércio, atrás de Brasil e Portugal, com trocas comerciais no valor de 280 milhões de dólares e um crescimento de $36,8 \%$. A constituição da Câmara de Comércio da China em Moçambique, em novembro de 2007, consolida os interesses dos dois países em formar um elo entre seus empresários, facilitando os negócios bilaterais. Espera-se que a Câmara sirva para fornecer aos empresários chineses informações sobre as políticas e regulamentos em vigor em Moçambique, que incluem um conjunto de medidas para encorajar o investimento chinês.

Avalia-se que o potencial econômico do País para a atração de investimentos nos setores de agro-indústria, turismo, pesca e mineração é muito grande. Projetos ao longo de todo o país, especialmente nos setores de transportes e turismo têm contribuído para posicionar Moçambique na rota dos grandes investimentos internacionais. Com relação aos provenientes da China, verifica-se que também têm sido modestos em comparação aos realizados em outros países da África. Mas, assim como acontece com a corrente de comércio bilateral, o investimento externo direto chinês alcançou altos níveis em poucos anos. Em meados de 2007, alcançou o valor de US\$ 12 milhões de dólares, um grande crescimento se comparado aos US\$500 mil de 2004. Com 
tal índice, a China posicionou-se em sexto lugar entre as fontes de IED para Moçambique.

Aspectos positivos da incursão de investimentos chineses são vistos na geração de empregos. Durante os anos de 1990 a 2007, os investimentos geraram 11.214 empregos. Em cerca de 17 anos de presença de empresas chinesas em Moçambique, as mesmas investiram aproximadamente 148 milhões de dólares, 69 milhões dos quais foram aplicados de 2003 a $2007^{32}$. As empresas da China no país estão destacadamente presentes nos setores de agricultura e agro-indústria, aqüicultura e pescas, indústria e construção. É notória a presença de empreendimentos chineses nas grandes obras, como a reconstrução dos sistemas de abastecimento de água nas principais cidades moçambicanas. O setor hidroelétrico é reforçado com o financiamento da construção de uma barragem no rio Zambeze.

No âmbito do Fórum para a Cooperação China-África, tinham sido determinadas como áreas-chave na cooperação entre China e Moçambique a agricultura e as infra-estruturas. O setor agrícola ainda emprega grande parte da força de trabalho do país e é responsável pela grande maioria das exportações moçambicanas. O vice-ministro de comércio chinês, Wei Jianguo, em uma visita a Moçambique, em março de 2006, anunciara uma ofensiva econômica. O representante referiu seus objetivos de avaliar possibilidades de investimentos em várias áreas, com destaque para as de produção e processamento agrícola, e de sua extensão para áreas de formação técnica e científica ${ }^{33}$.

Em fevereiro de 2007, Hu Jintao realiza uma visita a Moçambique, com vistas a confirmar, reforçar e traçar perspectivas em relação à estratégia cooperativa bilateral, no âmbito da política africana da China. Houve grande expectativa de que as autoridades moçambicanas apresentassem propostas concretas de permitir que o país aceda aos fundos acordados na FOCAC de

\footnotetext{
32 "Moçambique: China gerou mais de 11 mil empregos desde 1990". MacauHub, 08.05.2008, disponível em http://www.macauhub.com.mo/.

33 "China anuncia investimento na agricultura de Moçambique". Agência Lusa, 23.03.2006, disponível em http://www.agencialusa.com.br/.
} 
novembro de 2006, desenvolvendo setores abrangidos pela iniciativa. No Fórum Sino-Africano de 2006, a China disponibilizou aos países africanos grandes somas para custear despesas nos domínios de capacitação técnica dos países do continente, combate à malária e HIV/AIDS, construção de centros de demonstração de técnicas agrícolas, entre outras iniciativas, no período entre 2007 e 2010. No caso de Moçambique, almejava-se a operacionalização da cooperação nas áreas de trocas comerciais e infraestruturas, antevendo-se também que as partes alcançassem um acordo de perdão da dívida moçambicana. O encontro finalizou com a inauguração das obras de construção do centro de demonstrações de tecnologias agrárias de Nampula $a^{34}$.

Da importante visita do presidente chinês, elaborou-se um comunicado conjunto sobre as relações bilaterais e assuntos internacionais de interesse comum. Segundo o comunicado, os líderes dos dois países concordaram em fortalecer o intercâmbio governamental, parlamentar e partidário, aprofundar a cooperação econômica e comercial, ampliar o intercâmbio cultural e buscar maior expansão dos laços bilaterais. Ambos os governos comprometeram-se a estimular suas empresas a cooperar no desenvolvimento agrícola e na construção das infra-estruturas, reforçar suas consultas e coordenações nos assuntos multilaterais e salvaguardar conjuntamante os interesses dos países em desenvolvimento.

Ao final da visita de Hu Jintao, os governos de Moçambique e da China assinaram diversos acordos de cooperação, incluindo o perdão da dívida de Moçambique e um crédito do banco governamental chinês Eximbank a Moçambique. Foram ainda rubricados acordos para o financiamento pela China da construção do futuro Estádio Nacional de Moçambique e para a concessão de um empréstimo preferencial chinês. Os dois países concordaram ainda em aumentar o número de produtos moçambicanos que terão isenção de taxas para entrarem na China, dos atuais 190 para 442, e a quantidade de categorias de bens a serem vendidos ao mercado chinês livres de encargos. Também

\footnotetext{
34 "Presidente da China em Moçambique para reforço da cooperação bilateral". Portal do Governo de Moçambique, 08.02.2007, disponível em http://www.govnet.gov.mz/.
} 
fizeram parte dos compromissos a construção de duas escolas técnicas em áreas rurais e o estabelecimento de um centro piloto de tecnologia chinesa em Moçambique, assim como foi decidido aumentar o número de estudantes bolsistas moçambicanos na China ${ }^{35}$.

Analistas afirmam que Moçambique apresenta potencial para a cooperação no setor de matérias-primas energéticas, tendo em consideração as suas supostas reservas de gás natural e de petróleo ainda por extrair. Há bons resultados das reformas tomadas em política econômica, assim como altos níveis de cooperação bilateral e potencialidades positivas no relacionamento com a China, mas ainda não se verificam melhores níveis de desenvolvimento em decorrência, tendo em vista que o país continua a ser classificado na posição dos mais pobres do mundo, por organizações como o Banco Mundial e o Fundo Monetário Internacional. Apesar do notável crescimento econômico que o País vem registrando, muitos moçambicanos continuam vivendo abaixo da linha da pobreza. O governo tem como uma das prioridades o combate à pobreza, mas o país ainda é muito dependente de ajuda externa para as finanças anuais. Soma-se às dificuldades um persistente desequilíbrio nas contas comerciais, mesmo com os ganhos provenientes das exportações. Percebe-se que superação dos obstáculos passa pela melhoria das infra-estruturas e da diversificação da base econômica de Moçambique.

\footnotetext{
35 "China perdoa dívida Moçambicana”. Portal do Governo de Moçambique, 08.02.2007, disponível em http://www.govnet.gov.mz/.
} 


\section{RELAÇÕES COM CABO VERDE, GUINÉ-BISSAU E SÃO TOMÉ E PRÍNCIPE}

Os três países escolhidos para a segunda parte da análise das relações entre China e os PALOP têm em comum o fato de os níveis de cooperação com o país asiático não se compararem aos reforçados laços que Angola e Moçambique têm conquistado. Os muitos desafios a enfrentar pelos países africanos em geral, para o alcance de relações efetivamente cooperativas com a China, aplicam-se de maneira mais evidente nos três menores PALOP. No entanto, é importante perceber, especialmente no contexto dos países lusófonos, uma maior atenção chinesa em relação a Cabo Verde, Guiné-Bissau e São Tomé e Príncipe, cada qual com suas razões para o incremento cooperativo.

Trata-se de um pequeno conjunto de países que também se assemelham no fato de apresentarem menores territórios e relativa escassez de recursos naturais. Mas há potencial para maiores fluxos de comércio e investimento, assim como iniciativas de ajuda ao desenvolvimento. Os Fóruns Sino-Africanos representaram a melhoria das relações, a partir de um renovado interesse chinês no continente negro, e de sua compatibilização pela recepção positiva por países que vêem nas relações econômicas com a China a possibilidade de superação da posição de pobreza.

Os países têm nas relações políticas e no envio de ajuda chinesa os pontos mais fortes da cooperação. No campo político, ressaltam-se as posições dos mesmos no tocante à questão do reconhecimento de Taiwan. No âmbito de uma nova e congratulada dinâmica na cooperação entre a China e os três PALOP referidos, percebe-se a extensão dos investimentos chineses na melhoria das infra-estruturas e sua aplicação em outros setores importantes para os países africanos em questão, tais como a pesca e o turismo em Cabo Verde, agricultura em Guiné-Bissau e petróleo em São Tomé e Príncipe.

Apesar de o volume de trocas comerciais estar muito aquém do observado por outros países africanos, como Angola, e de o comércio se concentrar nas exportações desses países africanos para a China, verifica-se o 
seu aumento nos últimos anos. Há positivas expectativas do estreitamento das relações, ainda mais se as partes considerarem importante a prospecção de fontes de recursos naturais e energéticos supostamente existentes na parte africana, como gás natural em Cabo Verde.

O trabalho passa para a fase de acessar a evolução do relacionamento de cada um dos países selecionados com a China, a fim de se avaliar fatores e contribuições para estado atual da cooperação, assim como traçar possíveis panoramas futuros, tendo em vista os objetivos de seu incremento, por parte dos países envolvidos na estratégia. 


\section{Cabo Verde: vocação de plataforma}

$\mathrm{O}$ arquipélago que tem histórica função de entreposto comercial, desde sua colonização pelos portugueses no século XV, aproveita o momento atual de vigoroso crescimento chinês e renascimento africano para destacá-la e estendê-la para a consideração de plataforma ${ }^{36}$. O país, pobre em termos de recursos naturais, tem força no setor de serviços, sendo que os setores de comércio, transporte, turismo e serviços públicos respondem, atualmente, por três quartos do PIB cabo-verdiano. Ainda dependente de importações, sobretudo produtos alimentares e equipamentos, e de ajuda externa, o país tem se beneficiado com o crescimento dos investimentos estrangeiros, a partir de progressiva incursão em estabilidade política e reformas estruturais.

A posição estratégica no cruzamento das rotas do Atlântico representava uma vantagem geoestratégica para as necessidades de expansão marítima, na época dos grandes decobrimentos. Com a abolição do tráfico de escravos em 1867, o interesse comercial do arquipélago decresceu, só voltando a ganhar importância a partir da metade do século $X X^{37}$. A decadência econômica e as constantes secas em seu árido solo impulsionaram uma forte emigração populacional da colônia nas primeiras décadas do século passado. Isso ainda tem resultados no período atual, quando se contabiliza que a população expatriada de Cabo Verde é maior que a doméstica.

A partir da década de 1950, com o surgimento dos movimentos de independência dos povos africanos, a colónia do Cabo Verde se vincula à luta pela libertação da antiga Guiné Portuguesa e atual Guiné-Bissau. O país tornou-se soberano no ano de 1975, quando as duas partes referidas passam a formar países separados e governados pelo mesmo partido único de orientação marxista, o Partido Africano para a Independência da Guiné e Cabo Verde (PAIGC). Em 1976, Cabo Verde estabelece relações diplomáticas com a

\footnotetext{
36 "Plataforma da China para mercados africano, europeu e americano". Embaixada da República de Cabo Verde no Brasil, 04/12/2007, disponível em http://www.embcv.org.br/.

37 "Dados gerais. Cabo Verde: Breve Apresentação", disponível em http://www.governo.cv/.
} 
China. Um plano de plano de unificação política com a Guiné-Bissau fracassou em 1980, após um golpe militar, a partir de quando a ala cabo-verdiana do partido se rompe com a da Guiné-Bissau e passa a se chamar Partido Africano para a Independência de Cabo Verde (PAICV), que, em momento posterior, renuciaria às idéias marxistas. As relações diplomáticas com Guiné-Bissau foram rompidas logo em seguida, mas seriam reatadas dois anos mais tarde ${ }^{38}$.

O período pós-independência foi governado por um regime de partido único que esteve no poder até 1991, ano em que optou-se pelo regime mutipartidário, iniciando um contexto de transição democrática. $O$ país, que ganhou uma Constituição democrática em 1992, estabilizando-se politicamente, passa a observar melhores taxas de crescimento econômico. As autoridades cabo-verdianas optam por uma economia de mercado, permitindo apresentar-se favorável ao investimento estrangeiro. As mudanças importantes que se verificaram nos últimos cinco anos, marcadamente assinaladas com a transição de um sistema econômico centralizado para uma economia de mercado, acrescidas do fato de se ter implantado um "Modelo de Inserção Dinâmica" de Cabo Verde na economia mundial, fazem do país um mercado preferencial de atração do investimento estrangeiro.

No seguimento do alcance de estabilidade política e reforço da estrutura econômica do país, realizaram-se reformas a vários níveis da vida econômica, da administração pública, do ensino e da educação. Os objetivos não se restringiram à aceleração do crescimento econômico, mas se buscou fazer com que esse crescimento se harmonizasse com um desenvolvimento social e humano. Ademais de encaminhar o país para maior atenção mundial, o governo tem logrado canalizar capacidades financeiras e técnicas no sentido de apoiar o espírito de iniciativa empresarial que marca a comunidade caboverdiana no exterior: as melhorias no setor financeiro foram reforçadas com o crescente fluxo de remessas da população emigrada. O crescimento do PIB de Cabo Verde tem observado bons níveis nos últimos anos, sendo que em 2005 e 2006, manteve-se estável em 6,5\%.

\footnotetext{
38 "O país: História". Disponível em http://www.governo.cv/index.php?option=com content\&task=view\&id=53\&ltemid=63.
} 
As reformas econômicas introduzidas pelo governo democrático no início do anos 90, optando por uma economia de mercado, visavam reestruturar 0 sistema econômico afim de atrair mais investimento estrangeiro para diversificar a economia. Estabeleceu como prioridades o desenvolvimento da promoção da economia de mercado e do setor privado, o desenvolvimento do turismo e das indústrias de manufatura e pesca, o desenvolvimento dos transportes, das comunicações e dos serviços energéticos. Verifica-se que as perspectivas futuras dependem da continuidade de programas de desenvolvimento, associados a fluxos de auxílio, e ao incentivo turístico, setor promissor para o país.

Em 2006, o ministro das Relações Exteriores chinês, Li Zhaoxing, visita Cabo Verde. O representante destacou o país africano como em parceria estratégica com a China, e apontou-o como um exemplo a seguir nas relações com a África, explicando a política externa chinesa para a África anunciada em janeiro daquele ano. Apoio político, benefícios econômicos mútuos e relação cultural próxima foram destacados para o seguimento de uma cooperação que tem sido bem-sucedida em diversas áreas. Em suas declarações a uma coletiva de imprensa anual sobre política externa, Zhaoxing disse que "Cabo Verde sempre defendeu a justiça, seguiu os princípios da Carta das Nações Unidas, na questão da reforma da organização e na defesa do princípio de uma só China (não reconhecendo Taiwan)", reforçando as ligações políticas. Em janeiro, o chanceler chinês assinou um acordo de cooperação que inclui um empréstimo sem juros de US\$2 milhões para a área da saúde ${ }^{39}$.

O apoio econômico e técnico, recebido historicamente da China, continua a se direciona para a melhoria das infra-estruturas. A construção dos edifícios do governo (Palácio da Várzea) e da Assembléia Nacional, na década de 1980, são marcas da cooperação chinesa em Cabo Verde, assim como a construção da primeira barragem do país africano, na ilha de Santiago. A modernização de hospitais e portos também atestam a realidade da cooperação.

39 "China destaca Cabo Verde em parceria estratégica com a África". Agência Lusa, 07.03.2006, disponível em http://www.agencialusa.com.br/index.php?iden=115. 
Com o estabelecimento do FOCAC, com destaque para o encontro de 2006, esperou-se que se realizassem grandes investimentos chineses no arquipélago, previstos para o setor portuário e hidrográfico em geral, com a construção de um novo porto marítimo na ilha de Santiago e novas barragens, o setor hospitalar, na construção de novas centrais de consultas, e outros, que envolvem unidades de cerâmica e material para construção, centros de pesca industrial e estádios nacionais. Espera-se que a edificação de infra-estruturas impulsione a implementação, com sucesso, da agenda de transformação em Cabo Verde, numa base de ganhos recíprocos para os povos dos dois países envolvidos no reforço cooperativo ${ }^{40}$.

Turismo, comércio e serviços também foram destacados como pontos a serem reforçados, de acordo com as expectativas de que o alcance de um novo grau de incremento cooperativo ajude no desenvolvimento do país. Cabo Verde pretende ser transformada num centro de destino turístico chinês no continente africano, com a continuidade dos investimentos realizados no setor, dos quais é exemplo a construção de um complexo turístico no ilhéu de Santa Maria, a partir de março de 2006 ${ }^{41}$. Pescas, transportes e serviços (novas tecnologias-chave e finanças) também são setores-chave da cooperação, e estão de acordo com a agenda cabo-verdiana de desenvolvimento.

Em matéria de comércio exterior, as exportações de Cabo Verde ainda são muito baixas, mas o volume de importações de bens chineses vem aumentando, sendo que, entre 2003 e 2005, o volume de exportações da China ao país africano quase duplicou. $O$ crescente número de estabelecimentos comerciais chineses na maioria das cidades do arquipélago é sinal da boa fase das relações bilaterais. A área de Plateau é denominada no país como "China Town" porque as lojas chinesas já contam como maioria do comércio nesta região da capital.

\footnotetext{
40 "Cabo Verde espera atrair mais investimentos chineses". Agência Lusa, 03.11.2006, disponível em http://www.agencialusa.com.br/index.php?iden=4544.

41 "Cabo Verde: chineses investem 100 milhões de euros no llhéu de Santa Maria". Agência Lusa, 07.03.2006, disponível em http://www.agencialusa.com.br/.
} 
Em julho de 2007, o Vice-Ministro do Comércio Chinês, Wei Jianguo, visita Cabo Verde, em resposta a um convite do Ministro dos Negócios Estrangeiros, Cooperação e Comunidades, Victor Borges, quando de sua recente visita à República Popular da China. Os acontecimentos objetivaram continuar os esforços bilaterais com vista ao aprofundamento das relações entre a China e Cabo Verde, especialmente nos domínios da cooperação para o desenvolvimento, e das relações econômicas, comerciais e empresariais.

Prospectos para a ampliação das áreas de cooperação são verificados nos setores empresarial, na área das tecnologias e da capacitação de recursos humanos. A partilha e a divulgação de informações sobre os benefícios do reforço e do aprofundamento da cooperação econômica e comercial favorecem melhores oportunidades de negócios. A tecnologia e a formação de quadros conferem incremento qualitativo à cooperação, sendo que o país africano já apresenta mão-de-obra relativamente educada e qualificada. Os interesses das partes vão além das relações bilaterais quando se afirma que o país africano deseja ser plataforma de entrada da China na sub-região da África Ocidental, onde se encontra o arquipélago. A privilegiada situação geográfica entre a África, a Europa e as Américas pode permitir à China uma base comercial e econômica que ajude o dragão na melhor conquista dos mercados, a partir da produção de serviços que podem ser exportados, por exemplo. Além disso, China afirma seu interesse no gás natural supostamente existente no mar cabo-verdiano, fato que anima expectativas de reforço da cooperação com Cabo Verde. 


\section{Guiné-Bissau: necessidades de recuperação}

O país, também conhecido como Guiné Portuguesa, e que integra além do território continental cerca de 40 ilhas que constituem o arquipélago dos Bijagós, está entre as nações menos desenvolvidas do globo, e depende fortemente da agricultura e da pesca. Guiné-Bissau foi uma colônia de Portugal desde o século XV até à sua independência, em 1974. A vila de Bissau foi fundada em 1697, como fortificação militar e entreposto de tráfico negreiro, que mais tarde viria a ser elevada a cidade, e a capital da Guiné-Bissau após sua independência. Os rios e a costa do território foram as primeiras partes colonizadas, enquanto que o interior só foi explorado a partir do século XIX.

Desde a independência, o país tem observado intensa movimentação política e militar. Em momento anterior, no ano de 1956, uma rebelião fora iniciada pelo Partido Africano para a Independência da Guiné e Cabo Verde (PAIGC), consolidando seu controle sobre o país em 1973. A independência declarada unilateralmente foi reconhecida por dezenas de países nos meses que se seguiram, sobretudo comunistas e africanos, enquanto que a antiga metrópole colonial só a reconheceu na Revolução dos Cravos, em 1974. O país foi controlado por um conselho revolucionário até 1984. No ano de 1980, estabeleceu-se um governo militar que tinha como predidente o ditador Joao Bernardo Vieira, fato que inviabilizou a pretendida união com Cabo Verde. $O$ regime, apesar de suprimir direitos políticos e eliminar elementos da oposição, iniciou o encaminhamento do país a uma economia de mercado e ao futuro sistema multipartidário. Em 1994, após tentativas de sua destituição, Vieira é eleito nas primeiras eleições livres. No entanto, em 1998, movimentos militares geraram uma guerra civil e conseguiram a saída do presidente, que retorna em 2005, após anos em que se alternaram um governo de transição e novos golpes.

Acredita-se que o momento atual, mais estável politicamente, é mais propício para a reconciliação nacional e a retomada do desenvolvimento econômico. Antes da guerra civil, as reformas mais bem-sucedidas do governo foram em comércio exterior e liberalização dos preços, com a ajuda do FMI e 
também do Banco Mundial. A austeridade fiscal e 0 incentivo ao desenvolvimento do setor privado deram novo fôlego à economia. O "Programa de Reforma do setor de Empresas de Estado" está entre os principais componentes dos programas econômicos e financeiros que o governo de Guiné-Bissau assinara com seus parceiros de desenvolvimento citados. Estruturas organizacionais e legialações complementaram um quadro de "desengajamento do Estado", e disso não exemplos a Unidade de Gestão da Reforma das Empresas Públicas e Mista, órgão gestor do processo de privatização, e a Lei Quadro de Privatizações, instrumento jurídico da reforma ${ }^{42}$.

Após a guerra, as medidas de recuperação lançadas pelo governo trouxeram alento à debilitada economia e recuperaram o PIB em 8\% em 1999. O governo seguiu buscando fluxos de ajuda internacional para a estratégia de redução da pobreza. Mas a deficiente economia de Guiné-Bissau sente seu agravamento pela devastação promovida pela guerra civil: o cenário de ruínas que compõe a paisagem das cidades se combinava à escassez de recursos para saúde, alfabetização, emprego e alimentação, fato muito visível até os dias atuais. Na luta contra o subdesenvolvimento, percebe-se que o país é altamente dependente de ajuda externa para a quase totalidade dos investimentos públicos.

As necessidades de reconstrução são gigantescas, tendo em conta os danos causados pela destruição de grande parte das infra-estruturas do país. Em 1998, a guerra civil fez cair o PIB em $28 \%$ e observou-se uma recuperação parcial em 1999. A produção agrícola caiu à volta de $17 \%$ durante o conflito, assim como a produção de castanhas de caju caíram até $30 \%$. Piorando a situação, no ano 2000 o preço das castanhas caíram em 50\% no mercado internacional, aumentando a devastação começada com a guerra civil. A castanha de caju e o algodão correspondem aos principais produtos de exportação, sendo que o preço das primeiras tem aumentado em anos mais recentes. A agricultura emprega cerca de $80 \%$ da força de trabalho, e a

\footnotetext{
42 "Política de Desenvolvimento do Setor Privado". Consulado Honorário da República da Guiné-Bissau, disponível em http://www.geocities.com/consuladogb/.
} 
produção da pouca terra arável (cerca de $10 \%$ do território) destina-se fortemente para o mercado interno. A atividade industrial, por sua vez, não se apresenta relevante, a não ser nos setores envolvidos no processamento de produtos agrícolas.

A partir do litoral do país, percebe-se que são abundantes os elevados os volumes de pesca. Avalia-se que, anualmente, podem atingir 250 a 350 mil toneladas. A exportação de produtos do mar e a emissão de licenças de pesca para estrangeiros constituem em boas fontes de divisas do país. A riqueza em recursos naturais é reforçada pela existência de jazidas com cerca de 200 milhões de toneladas de fosfato e cerca de 100 milhões de amianto, além de matérias primas para o cimento. $\mathrm{A}$ isso se somam os potenciais de aumento da produção petrolífera, que já alcança 400,000 mil barris de petróleo por dia. Não se pode esquecer que o país apresenta reservas ainda por explorar de bauxita e de fosfato ${ }^{43}$.

A China aproxima-se do país lusófono a partir de laços que remontam ao "período da luta armada pela libertação". Recentemente, o reforço das relações bilaterais é verificado principalmente em ajuda ao desenvolvimento. Donativos em recursos financeiros e materiais vêm sendo concedidos nos últimos anos, com destaque para equipamentos agrícolas e cereais como o arroz, base da dieta alimentar de Guiné-Bissau. Em novembro de 2006, a partir de conversações entre os presidentes Vieira e Hu Jintao, foram identificados como setores privilegiados da cooperação bilateral a pesca e a agricultura. $O$ presidente guineense disse que gostaria de ver seu país começar a exportar para o mercado chinês algumas das 120 mil toneladas de castanhas de caju que produz por ano, apontando para possibilidades da extensão da cooperação em comércio.

A Guiné-Bissau foi o primeiro país do mundo a assinar com a China acordos de cooperação no setor da pesca de águas profundas, que já ultrapassam os vinte anos. Há prospectos para o incremento cooperativo quando se verifica suas possibilidades em relação a recursos minerais como

\footnotetext{
43 "Estudo de Mercado dos Países de Língua Portuguesa", Instituto de Promoção do Comércio e do Investimento de Macau, disponível em http://www.ipim.gov.mo/.
} 
fosfato, bauxita, e petróleo. A China tem sido grande aliada na recuperação das infra-estruturas do país, com vários projetos em curso e outros já terminados, como a nova sede da Assembléia Nacional Popular (o parlamento guineense), o Estádio Nacional 24 de Setembro, ou a reabilitação do Hospital Regional de Canchungo ${ }^{44}$. Além da cooperação em agricultura, saúde e infra-estruturas públicas, o estreitamento de laços incorpora o fornecimento de bolsas de estudos para a formação de quadros guineenses em escolas e instituições chinesas ${ }^{45}$.

A ajuda econômica e financeira vem aumentando, sendo que destaques são conferidos aos apoios concedidos em janeiro e junho de 2007, em seguimento aos pontos acordados nos fóruns multilaterais entre China e os países africanos. Em janeiro, durante a visita do ministro das relações exteriores chinês, Li Xiaozing, foi concedido a Guiné-Bissau um envelope financeiro de US\$ 4 milhões. Na ocasião, a China se comprometeu a abrir seu mercado à exportação de 442 produtos guineenses. Representantes dos dois lados saúdam uma nova etapa do relacionamento bilateral, que também envolve o apoio a empresários chineses que queiram nele investir ${ }^{46}$.

Apesar de o comércio bilateral ainda ter um longo caminho pela frente, a China já se figurava entre os principais destinos das exportações guineenses, respondendo por $4,2 \%$ de seu total, em 2004. Verifica-se que a China pode constituir-se em bom parceiro comercial quando se leva em conta as recentes altas demandas por commodities. O país asiático é um grande potencial para o mercado de cimento, por exemplo; com um quinto da população mundial, a China consume metade do cimento produzido em todo o mundo, além de um terço do aço e mais de um quarto do alumínio ${ }^{47}$.

\footnotetext{
44 "'Queremos que a China nos ensine a pescar', diz Guiné-Bissau". Agência Lusa, 03.11.2007, disponível em http://www.agencialusa.com.br/index.php?iden=4542.

45 "China oferece 100 bolsas de estudo para a formação de quadros guineenses". Notícias Lusófonas, 01.08.2007, disponível em http://www.noticiaslusofonas.com/.

46 "China dá apoio de R \$ 8,6 mi e abre mercado à Guiné-Bissau". UOL Notícias, 03.01.2007, disponível em http://noticias.uol.com.br/economia/ultnot/lusa/2007/01/03/ult3679u1036.jhtm.

47 "China's Quest for Resources”. The Economist, 13.03.2008
} 
A transformação das conquistas de crescimento econômico, a partir de reformas no sentido da liberalização e do proveito da incursão chinesa, em melhores níveis de desenvolvimento econômico e social passa pela continuidade e pelo aprimoramento da direção tomada. Nos últimos anos, o governo tem conferido prioridade ao desenvolvimento da agricultura, indústria e infraestruturas, da reforma do sistema econômico e das empresas estatais, bem como tem incentivado o investimento privado. A partir de 2004, 0 crescimento do PIB reverte uma tendência negativa e passa a aumentar gradualmente, chegando a atingir o valor razoável de 3.7\% em 2007. Mas percebe-se que o setor privado, que tem alcançado certo desenvolvimento após a liberalização da economia no final dos anos 1980, e as reformas macroeconômicas de disciplina orçamentária e redução da taxa de inflação fatos que tinham permitido uma taxa de crescimento em torno de $7 \%$-, ainda é pouco expressivo devido a fatores estruturais como a restrição do mercado interno e a fragilidade das infra-estruturas.

A má qualidade dos indicadores sociais, que remontam a dados como expectativa de vida, mortalidade infantil, alfabetização e nível de pobreza, são grandes obstáculos ao alcance de bons níveis de desenvolvimento econômicosociais. Segundo o FMI, A economia e as instituições governamentais da Guiné-Bissau permanecem "extremamente frágeis", as receitas públicas insuficientes e o governo dependente de ajuda externa para responder aos compromissos financeiros. ${ }^{48}$ Ao país que deseja superar baixos índices econômico-sociais, cabe tirar proveito da incursão chinesa e incorrer em adequadas medidas que permitam realizar os potenciais existentes. GuinéBissau é um dos poucos países da África em condições de exportar alimentos, como castanha de caju, peixes e algodão, e as reservas de petróleo em sua plataforma marítima poderão trazer os recursos tão necessitados.

\footnotetext{
48 "Economia e instituições 'extremamente frágeis' e dependentes de ajuda". MacauHub, 12.11.2007, disponível em http://www.macauhub.com.mo/pt/news.php?ID=4347.
} 


\section{São Tomé e Príncipe: superando obstáculos políticos}

São Tomé e Príncipe é um estado insular localizado no Golfo da Guiné, composto por duas ilhas principais (São Tomé e Príncipe) e várias ilhotas. Foi uma colônia de Portugal desde o século XV até sua independência em 1975. A cana-de-açúcar foi introduzida nas ilhas naquele século, mas a concorrência brasileira e as constantes rebeliões locais levaram a cultura agrícola ao declínio no século XVI. Assim sendo, a decadência açucareira tornou as ilhas entrepostos de escravos. A agricultura só foi estimulada no arquipélago no século XIX, com o cultivo de cacau e café. O país tornou-se altamente dependente do cacau desde a independência, em 1975.

Em 1960, surge um grupo nacionalista opositor ao domínio português, que dá origem ao Movimento de Libertação de São Tomé e Príncipe (MLSTP), de linha marxista, em 1972. Após a independência, alcançada em 1975, foi implantado um regime socialista de partido único sob o comando do MLSTP. A partir de 1987, o partido passa a promover mudanças de viés democrático e funde-se ao Partido Social-Democrata (PSD). A abertura econômica do país inicia-se dez anos após a independência, e, em 1990, adota-se uma nova constituição, que institui o pluripartidarismo. As primeiras eleições livres foram realizadas em 1991, mas freqüentes conflitos entre os partidos precipitaram repetidas mudanças nas lideranças são-tomeenses. No entanto, predominou a estabilidade política no país e maior fluidez nas relações entre o governo e as Forças Armadas.

Os problemas de pobreza verificados no país têm sido agravados com o declínio da produção de cacau, devido a períodos de seca e à falta de adequado gereneciamento. A São Tomé e Príncipe é necessário importar todos os combustíveis, a maioria dos bens manufaturados, muitos bens de consumo e quantidades substanciais de alimentos. Ao longo dos anos, o país enfrenta dificuldades para saldar sua dívida externa, e tem se apoiado em ajuda estrangeira e negociação da dívida. Benefícios vieram com o alívio da dívida sob o Programa para os países Altamente Endividados, e com a assinatura do 
um Programa de Redução da Pobreza e Facilidades ao Desenvolvimento, juntamente ao FMI.

Medidas de liberalização têm sido tomadas, no sentido do favorecimento à iniciativa privada interna e externa. O governo tem tentado reduzir controles de preços e subsídios. A atividade pesqueira continua a ser uma das principais atividades econômicas do país, e grande parte da população está envolvida nas atividades de agricultura de subisistência, mas o setor de serviços responde a mais de $70 \%$ do PIB de São Tomé e Príncipe. A indústria limita-se à transformação dos produtos agrários.

Há potencial considerável para o desenvolvimento do setor de turismo, a partir da privilegiada localização geográfica e de paisagens pitorescas, e o governo tem tomado medidas para expandir facilidades nos anos recentes, tendo em vista as contrubuições do setor para melhorias econômicas no país. A recente descoberta de jazidas de petróleo em suas águas abriu novas perspectivas para o futuro. O crescimento do PIB tem obtido níveis favoráveis, a partir de aumento de gastos públicos e de investimentos de capital relacionados ao petróleo. Em 2007, seu resultado ficou acima dos 6\%.

As relações com a China envolvem dificuldades em aspectos políticos, pois as relações diplomáticas foram suspensas em 1997, quando autoridades de São Tomé e Príncipe reconheceram diplomaticamente Taiwan. Entretando, a China tem aproximado do país lusófono no âmbito de sua política de reforço das ligações econômicas e comerciais com os países africanos lusófonos, já que o Fórum para a Cooperação entre China e os países da CPLP não tem caráter político. Representantes do país africano ressaltam a vontade de cooperar com a potência emergente da Ásia no sentido de permitir ao arquipélago relançar sua economia, por meio de parcerias com agentes econômicos chineses.

O presidente de São Tomé e Príncipe afirma uma "postura realista" de evitar "virar as costas para a China", reconhecendo a aproximação bilateral com os convites feitos a São Tomé para participar como observador no Fórum 
de Cooperação Econômica China-África ${ }^{49}$. Já o primeiro ministro Patrice Trovada refere que, apesar de o país ter optado por reconhecer a República da China (Taiwan) em 1997, um dos principais parceiros de cooperação atualmente, o país não considera a China Popular um adversário ou inimigo, e aponta que a opção de abandonar São Tomé e Príncipe foi tomada unilateralmente pela China Popular. O representante acredita em ver os problemas que existem entre China Popular e Taiwan ser ultrapassados num futuro breve "de uma maneira pacifica e preservando os interesses dos respectivos estados" 50 .

As declarações dos representantes surgem numa altura em que se confirma a existência de algumas movimentações entre os dois países, como delegações de empresários chineses interessados em explorar oportunidades de investimento. Sinal do crescente interesse da China em São Tomé e Príncipe é a recente compra da petrolífera chinesa Sinopec de participações em diversos blocos petrolíferos, que começaram a ser explorados em 2008. Além do petróleo, investimentos são esperados nos setores imobiliário e de construção civil.

Partidos políticos de São Tomé defendem a normalização das relações com Beijing, por considerar a China um gigante comercial inegável capaz de ajudar o país africano a atingir um desenvolvimento sustentado, invertendo as debilidades de produção interna, resolver crises energéticas e a falta de infraestruturas. O comércio bilateral ainda é pouco significativo, e tem sido concentrado nas exportações chinesas para o arquipélago.

Entre as dificuldades para se chegar a um novo patamar de desenvolvimento, está a extrema falta de diversificação da produção, ademais das frágeis estruturas industriais. O comércio exterior do país é dominado pela exportação da cacau, que tem representado cerca de $95 \%$ do valor das vendas

\footnotetext{
49 "São Tomé e Príncipe evita virar as costas para a China". UOL Notícias, 13.12.2007, disponível em http://noticias.uol.com.br/ultnot/lusa/2007/12/13/ult611u76017.jhtm.

50 "Primeiro ministro garante: as relações diplomáticas entre São Tomé e Taipé vão manter-se". Jornal Vitrina São Tomé e Príncipe, 19.03.2008, disponível em http://www.vitrina.st/AsAprova.htm.
} 
externas. O país apresenta mais da metade de sua população abaixo da linha da pobreza, sendo que a maioria da força de trabalho é composta por pessoal de baixa qualificação, problemas verificados em muitos dos países africanos. Maiores níveis de liberalização da economia e de redução da pobreza são condições importantes para que o crescimento econômico se transforme em desenvolvimento, sendo que seus prospectos ainda se encontram distantes.

Os governos recentes têm esperança de assegurar uma utilização racional e socialmente justa dos possíveis ingressos orçamentários decorrentes do início da exploração de peróleo, dos investimentos no setor de turismo e da recuperação do setor agrícola. Com estabilidade política e um quadro econômico mais favorável, analistas afirmam que São Tomé possa entrar e permanecer em fase de crescimento, ainda mais com a aproximação com as "duas Chinas". A promoção do desenvolvimento sustentável passa pela superação de carência infra-estrutural, especialmente deficiente no setor energético, e em melhorias em saúde e educação, metas que podem ser conquistadas com a combinação do apoio asiático e medidas do governo santomeense. 


\section{CONCLUSÃO}

As observações referentes ao atual estado das relações sino-africanas remetem a uma percepção geral de que o continente está sendo descoberto pela terceira vez, depois das feitorias de escravos e outras mercadorias, na época das grandes navegações, e da partilha neocolonial entre as potências européias, na passagem entre os séculos XIX e XX. O capitalismo global desembarca no continente neste início de milênio, quando potências mundiais e países emergentes voltam-se para as últimas reservas inexploradas de recursos naturais valiosos, que não se restringem ao petróleo. A China lidera a nova corrida às riquezas africanas, combinando necessidades de assegurar energia e matérias-primas para sustentar seu vertiginoso crescimento econômico e de abundantes capitais para exportar.

A gigantesca fome do dragão por recursos naturais, vista no fato de as importações destes recursos estarem crescendo ainda mais rapidamente que a sua economia, que já alcança um crescimento médio de $9 \%$ ao ano nas últimas duas décadas, tem contribuído para a elevação do preço de combustíveis, metais e grãos a níveis recorde nos últimos anos. Os países da África que os apresentam abundantes em seu território têm se beneficiado deste movimento. Mas o interesse chinês em seu acesso não é o único motivo para 0 estreitamento de laços: comércio e investimentos caracterizam fortemente as relações sino-africanas, sendo que, a partir do lançamento de uma nova era de cooperação com os fóruns multilaterais, a atividade econômica tem crescido vigorosamente entre as partes.

O governo chinês tem encorajado empresas a buscar contratos com países ricos em petróleo, gás natural e outros recursos, ao mesmo tempo em que estabelece consultas diplomáticas e acordos comerciais, perdão de dívidas e pacotes de ajuda. Os empreendimentos chineses vêm na África um excelente mercado para seus produtos, geralmente bens de consumo de baixo custo e com crescentes níveis de qualidade, assim como notam grandes oportunidades com as privatizações das indústrias africanas e a abertura das economias dos países africanos ao investimento estrangeiro. As boas taxas de crescimento 
econômico registradas pelo continente em geral se devem em grande parte aos investimentos chineses ${ }^{51}$, e a melhoria das infra-estruturas é realidade bem visível na maioria das nações da África, em maior ou menor nível.

Aos países africanos interessa o alcance de melhores níveis de desenvolvimento econômico e social, e a incursão chinesa é vista como boa oportunidade para tal meta. Apesar do crescimento econômico observado nos anos recentes, a África de junta ao mundo globalizado "atrasada, com carência urgente de capitais e conhecimentos que a capacitem a embarcar em um novo ciclo de desenvolvimento. As reformas realizadas a partir das décadas de 1980 e 1990, no sentido da mudança de atitudes em relação ao capital estrangeiro, quando se abandona o protecionismo é passa a ser abandonado e o continente volta-se a tendências e práticas que ajudem a maximizar as vantagens potenciais e os positivos efeitos macroeconômicos que o investimento direto estrangeiro pode prover, representaram avanços importantes para as economias dos países.

Mas a tradução dos benefícios do livre mercado em desenvolvimento econômico não se dá diretamente, pela simples abertura comercial ao mundo, por exemplo, mas sim deve acompanhar políticas que canalizem tais benesses para reais melhorias internas em termos sócio-econômicos. Reconhece-se, assim, o importante papel dos Estados na promoção e no gerenciamento do processo de desenvolvimento econômico, mediante decisões de investimentos, certo apoio às firmas locais e manutenção de disciplinas fiscal e monetária. A noção de livre mercado, apesar de parecer eliminar as possibilidades da alocação de recursos baseada em autoridade, substituindo esta por contratos voluntários, não se aplica em um sentido de absoluta liberalização, mas sim de redução do intervencionismo governamental. Não se afasta a noção de poder dos Estados, já que, de acordo com Keohane, "em qualquer lugar da economia em que há atores exercendo poder sobre outros, a economia é política”52.

\footnotetext{
${ }^{51}$ PAN, Esther. "China, Africa and Oil". Council on Foreign Relations, 26.01.2006, disponível em http://www.cfr.org/publication/9557/.

52 CORPORASO, James A.; LEVINE, David P. "Theories of Political Economy". Cambridge: Cambridge University Press, 1992.
} 
A tarefa de se retirar da pobreza uma grande massa populacional e levá-la a níveis aceitáveis de bem-estar econômico-social pode ser alcançada mediante o estabelecimento de políticas econômicas em conformidade com o mercado e as forças transnacionais nele atuantes, e sua conjugação com a redução do Estado em algumas áreas de atividade econômica não tradicionalmente associadas ao setor público e a promoção de atuação positiva em terrenos onde ele possui certa "vantagem comparativa", tais como infraestrutura, educação, lei e ordem e serviços públicos básicos, onde administração e organização são importantes. Anne Krueger, em sua análise sobre as "falhas de governo", divide-nas em falhas de comissão, quando observam-se resultados insatisfatórios de política econômica com programas de investimento de altos custos e baixa eficiência, controles sobre o setor privado, déficit do setor público e inflação, e falhas de omissão, em que a deterioração de facilidades de transporte e comunicação, controles cambiais e licenciamento de importações se encaixam. Somam-se a esse conjunto práticas de corrupção visíveis e de larga escala, envolvendo programas de superação da pobreza que beneficiam desproporcionalmente os membros mais afluentes da sociedade ${ }^{53}$.

É fato amplamente reconhecido, especialmente após o triunfo das teorias e práticas liberais, que a abertura da economia de um país, acolhendo novas tecnologias e competindo com o resto do mundo, leva esse país a tornar-se participante do progresso a nível mundial. Mas a liberalização não exclui a importância do ente estatal, na medida em que adequadas políticas estatais são condutoras às almejadas metas de desenvolvimento. A partir do exemplo dos países africanos, considerou-se um grau inicial muito elevado de inflexibilidade e isolamento como ponto de partida para processos de reforma, pelo qual a economia passa de um sistema protegido para outro aberto ao comércio livre de produtos e a fluxos de capitais. Não é fácil determinar quais as políticas corretas a serem seguidas de acordo com o momento, e não é verdade que sua implementação não ofereça problemas. É preciso que as

\footnotetext{
53 KRUEGER. Anne O. "Government Failures in Development". The Journal of Economic
} Perspectives, Vol. 4, No. 3, Summer, 1990, pp. 9-23. 
principais políticas se concentrem na direção certa para que a performance econômico-social revele sucesso considerável.

Um grupo heterogêneo de países tanto caracteriza a África Sub-saariana como o grupo de países africanos de língua oficial portuguesa, cada um com diferentes economias, populações e elementos geográficos. O debate sobre a liberalização a fluxos de comércio e investimentos ainda se revela inconclusivo, envolvendo falsas considerações; a partir disso, busca-se evitar generalizações - nenhuma proposta de política econômica envolvendo o comércio internacional pode ser totalizante, devendo ser buscadas soluções caso a caso, em termos de bens, setores econômicos e condições próprias de desenvolvimento dos países em questão.

A liberalização econômica precisa ser acompanhada de políticas macroeconômicas adequadas que levem em consideração os prováveis desequilíbrios internos e externos da economia durante a transição. Os benefícios da liberalização já são verificados no conjunto dos países lusófonos, especialmente com o recente incremento cooperativo com a China, e envolvem ganhos de eficiência do lado da produção, mediante receitas de exportação, e também do lado do consumo, quando os produtos podem ser obtidos a preços menores e qualidades maiores. Mas os custos não devem ser desconsiderados, e importa a tomada de decisão quanto à possibilidade de arcar com os mesmos, que ocorrem normalmente a curto e médio prazo, com vistas a melhorias gerais no prazo estendido. Os custos da abertura normalmente são de caráter redistributivo, já que os setores antes protegidos tendem a "perder", ao menos temporariamente. Mas também é preciso lembrar que a ajuda de governos estrangeiros ao processo de ajustamento pode acelerar a reforma e reduzir seus efeitos colaterais ${ }^{54}$.

Os Fóruns realizados entre China e os países do continente africano representaram excelentes oportunidades para os mesmos se beneficiarem do mercado emergente chinês. Para se alcançar um amplo desenvolvimento

\footnotetext{
${ }^{54}$ DORNBUSCH, R.; LESLIE HELMERS, F. C.H. "Economia Aberta: Instrumentos de política econômica nos países em vias de desenvolvimento". Fundação Calouste Gulbenkian, Lisboa, 1991.
} 
econômico, cabe aos países africanos a criação de um ambiente ainda mais permissivo para o engajamento na produção valor agregado em recursos naturais e outros setores, e para a participação nas cadeias globais, atraindo mais investimento externo direto, tendo em vista que uma quantidade muito grande dele é necessária para que tais países deixem uma condição de muito atraso. Verifica-se que ainda existem obstáculos para o estebelecimento de uma "atmosfera de desenvolvimento", capaz de mudar o continente, presentes nos gargalos de infra-estrutura, na pouca diversificação da pauta de produção e exportação, e na vigência de escalada tarifária ${ }^{55}$.

No tocante às repercussões a nível mundial, especialmente em relação ao Ocidente, a "invasão chinesa" preocupa as antigas metrópoles coloniais européias, que perdem espaço econômico e político no continente africano, enquanto ele atrai atenções e iniciativas de potências emergentes, como Brasil e Índia. O continente em geral, que tem sido entreposto histórico dos interesses dominantes na economia e geopolítica mundial, com fronteiras traçadas artificialmente como resultado da exploração imperialista, vê muitas vantagens da incursão da China em seus países, a partir de sua consideração como também país emergente. A não interferência em assuntos domésticos, a partir da separação entre política e negócios, a ausência de condicionalidades em relação a governança e probidade fiscal, o investimento em áreas geralmente negligenciadas por agências de ajuda e investidores privados ocidentais (infraestrutura física, indústria e agricultura), o pouco tempo e a boa qualidade dos projetos, e as grandes somas investidas são características da atuação chinesa muito bem recebidas pelos países que precisam superar grandes níveis de subdesenvolvimento.

O atual padrão de comércio bilateral remete às esportações chinesas de commodities de maior valor agregado, tais como têxteis, apparel, máquinas e equipamentos elétricos, bens de consumo (remédios, cosméticos e baterias), sendo que os mesmos correspondem a $87 \%$ das importações africanas da China, assim como às exportações africanas de petróleo e matérias-primas,

\footnotetext{
${ }^{55}$ A escalada tarifária se verifica quando produtos africanos com maior grau de processamento recebem tratamento tarifário diferenciado de outros em fase mais bruta, quando de seu acesso ao mercado chinês.
} 
totalizando mais de $62 \%$ das exportações totais para o país asiático, seguidas de ferro e metais. Os produtos manufaturados contam com apenas $20 \%$ do total das exportações africanas a nível mundial, padrão que também se aplica ao comércio com a China. No entanto, verificam-se sinais de mudança com a crescente importação chinesa de exportações africanas de manufaturas leves, ainda que limitadas por tarifas. ${ }^{56}$

No tocante aos investimentos, os movimentos se dão na direção do estabelecimento de joint-ventures entre empresas estatais chinesas e suas homólogas africanas, para assegurar fontes de commodities. Disso é exemplo a parceria da chinesa SINOPEC com a angolana SONAGOL em exploração de petróleo, que vai além com planos de construção de refinarias. O recurso energético tem sido crescentemente demandado e aumentado em seu preço, o que reforça as tendências de encorajamento de maior exploração das fontes exisetentes, prospecção de novas, construção de unidades de refinamento e facilitação de distribuição. A China, país em desenvolvimento que enfrentou 0 desafio de atender às demandas de consumo para impulsionar seu desenvolvimento econômico, diante de sua pouca disponibilidade de hidrocarbonetos, tornou-se importador líquido em 1993, na época o terceiro maior importador de petróleo depois de Estados Unidos e Japão. Há que se considerar que sua oferta é determinada, entre outros fatores, pela evolução de regimes políticos em países como Arábia Saudita, Irã e Iraque. Os problemas de instabilidade presentes no Oriente Médio favorecem a busca de fontes alternativas, e países do continente africano que já possuem o recurso ou apresentam grandes potenciais nesse sentido são muito atrativos para 0 dragão emergente.

Mas os fluxos de investimentos não se resringem à área do petróleo. $A$ emergência de forte crescimento em países que não fornecem petróleo é testemunha da influência das reformas macroeconômicas que têm estabilizado taxas de inflação, aumentando valores cambiais e encorajando o investimento do setor privado em níveis nacional e internacional. Percebe-se que estes se destinam amplamente aos setores de energia e telecomunicações, e a projetos

\footnotetext{
${ }^{56}$ BROADMAN, Harry G. "Connecting Asia and Africa". Finance \& Development, June 2007.
} 
nas áreas dos transportes, das infra-estruturas públicas, econômicas e sociais e do setor produtivo. No que se refere à ajuda econômica da China para os países africanos, verificou-se o seu significativo aumento, na forma de empréstimos preferenciais e livres de juros, garantias, alívio da dívida, doações e assistência técnica. Mas há que se reconhecer o fato de que os fluxos de ajuda são acompanhados de acordos para o desenvolvimento de recursos minerais e energéticos.

O conjunto de países africanos selecionados para a pesquisa apresenta como obstáculos à tradução das incursões do capital internacional em desenvolvimento mercados de capitais ineficientes, pouco trabalho qualificado e falta de adequadas infra-estruturas, apesar de reformas terem sido realizadas para superá-los. É praticamente consensual entre analistas que o estabelecimento de reformas mais abrangentes ou o aprofundamento das já existentes envolvem o estímulo à competição doméstica entre empresas, a flexibilização dos mercados de trabalho e capital, muitas melhorias em infraestrutura e medidas aduaneiras liberalizantes. $O$ aumento e a diversificação das exportações, a redução das dívidas interna e externa, e o uso adequado dos recursos da ajuda estrangeira para educação e saúde completam as fundações para um crescimento econômico de longo prazo.

Um salto adiante já é observado com o reconhecimento da habilidade da economia capitalista de mercado de gerar riqueza, mas o almejado desenvolvimento é alcançado se forem tomadas medidas para a expansão da capacidade da sociedade de satisfazer suas necessidades - daí o bem-estar econômico e social. O papel do Estado nessa meta envolve sua concentração na oferta de bens e serviços que apresentem externalidades positivas, como infra-estrutura física e institucional, justiça, segurança e educação ${ }^{57}$. O estímulo de ações produtivas e cooperativas entre os agentes econômicos, assim como de um bom grau de concorrência na oferta de bens e serviços, juntamente com a provisão de redes, energia e comunicações, e a melhoria do estoque de capital humano da sociedade, constituem fundações de produtividade capazes de beneficiar as sociedades dos países que nelas incorrem.

\footnotetext{
${ }^{57}$ PIO, Carlos. "Relações Internacionais: economia política e globalização”. Brasília: IBRI, 2002.
} 
A estratégia cooperativa tem grandes chances de continuar seu aprofundamento. Torna-se necessário afastar considerações de "disfarce" sobre o termo "cooperação", ao ser ligado a adaptações da velha política de colonização, om que prejudica a visível necessidade de um relacionamento cooperativo para as economias ainda atrasadas atingirem melhores níveis de desenvolvimento. A existência de efetiva cooperação é notada quando se considera o atual padrão das relações entre China e os PALOP como um que está no caminho da promoção do "poder compartilhado", noção derivada das considerações dos autores Corporaso e Levine, quando se referem a um padrão em que a colaboração é necessária para a conquista dos fins, em que objetivos que não estejam necessariamente em oposição, e em que ganhos superam perdas ${ }^{58}$. A incursão externa representada pelo dragão do Leste Asiático é acompanhada de retórica e também de ações que vão no sentido dos benefícios mútuos.

As relações, que datam de muitos anos e vêm conhecendo fases muito significativas onde os resultados palpáveis têm sido conseguidos, são intensificadas no seguimento dos princípios de amizade sincera, tratamento igual, apoio mútuo e desenvolvimento comum, de modo a enfrentar as provas da história e as mudanças do cenário internacional. A tradução das iniciativas de reforço da relação entre China e os PALOP em alcance e manutenção de desenvolvimento dependerá da disposição e do empenho dos agentes políticos, econômicos e sociais envolvidos em encarar com seriedade as necessidades de superação de estágios mais atrasados em busca da prosperidade econômico-social.

\section{BIBLIOGRAFIA}

\footnotetext{
${ }^{58}$ Os autores diferenciam o exercício de "poder compartilhado" das noções de "poder para assegurar fins sobre a natureza, e de "poder sobre outros".
} 
BROADMAN, Harry G. "Connecting Asia and Africa". Finance \& Development, June 2007.

BROADMAN, Harry G. "China and India Go to Africa". Foreign Affairs, Vol. 87 no. 2, March/April 2008.

CIA. The World Factbook 2008. Central Intelligence Agency, March 2008.

CORPORASO, James A.; LEVINE, David P. "Theories of Political Economy". Cambridge: Cambridge University Press, 1992.

DORNBUSCH, R.; LESLIE HELMERS, F. C. H. "Economia Aberta: Instrumentos de política econômica nos países em vias de desenvolvimento". Lisboa: Fundação Calouste Gulbenkian, 1991.

FEIJÓ SOBRINHO, Pedro da Silva. "Comunidade dos Países de Língua Portuguesa. Institucionalização e relações culturais, político-diplomáticas e econômicas". Rio de Janeiro: Revan, 1997.

GILPIN, Robert. "Global Political Economy". Princeton, NJ: Princeton University Press, 2001.

HONG-MING, Zhang. "A Política Chinesa na África". In: Bellucci, Beluce (org.). "Abrindo os olhos para a China". Rio de Janeiro: EDUCAM, UCAM, 2004, pp. 233-196.

JACOBY, Ulrich. "Getting Together. The New Partnership Between China and Africa for Aid and Trade". Finance \& Development, June 2007.

JIRU, Shen. "A Estratégia Internacional Chinesa no Século XXI". In: Bellucci, Beluce (org.). "Abrindo os olhos para a China". Rio de Janeiro: EDUCAM, UCAM, 2004, pp.335-371.

KANINDA, John. "O salto gigante de Angola no palco da economia mundial". Business Day, Dezembro 2005.

KEOHANE, Robert O. "Economics, Inflation and the Role of the State: Political Implications of the McCracken Report." World Politics 31, no. 1, October 1978, pp. 108-128.

KEOHANE, Robert O. "Power and Interdependence. World Politics in Transition." Boston: Little Brown, 1977.

KRUEGER. Anne O. "Government Failures in Development". The Journal of Economic Perspectives, Vol. 4, No. 3, Summer, 1990, pp. 9-23.

MASLAND, Tom. "Africa Leaps Forwards". Newsweek, 11.07.2005. 
MENZIES, Gavin. "1421: The Year the Chinese Discovered the World", London: Bantam Press, 2003.

MUEKALIA, D. J. "Africa and China's Strategic Partnership". African Security Review 13, no. 1, 2004, pp. 5-11.

PIO, Carlos. "Relações Internacionais: economia política e globalização". Brasília: IBRI, 2002.

SARAIVA, José Flávio Sombra. "Comunidade dos Países de Língua Portuguesa (CPLP). Solidariedade e Ação Política". Brasília: IBRI, 2001.

SILVA, Aristides. "Economia Internacional. Uma Introdução". São Paulo: Atlas, 1986.

SNOW, Philip. "The Star Raft: China's Encounter With Africa". New York: Weidenfeld and Nicholson, 1988.

WALTZ, Kenneth N. "Theory of International Politics". New York: Mc Graw-Hill, 1979.

\section{Fontes da Internet}

ASHBY, Tom. "China seeks 'strategic partnership' with Africa". The Boston Globe. 27.04.2006, disponível em http://www.boston.com.

CONSELHO EMPRESARIAL BRASIL-CHINA. "Carta da China.", ano 3, ํo 16, 30.03.2006, disponível em http://www.cebc.com.br/.

CRAVINO, Janete. "Conflitos Internos - Resolução de Conflitos". Revista Militar, 14.12.2005, disponível

http://www.revistamilitar.pt/modules/articles/article.php?id=21.

HANSON, Stepnahie. "China, Africa, and Oil", Council on Foreign Telations, 06.06.2008, disponível em http://www.cfr.org/.

JIA, Annie. "Roundtable probes the politics of China's large-scale investments in Africa". Stanford Report, 16.05.2007, disponível em http://newsservice.stanford.edu/

LYMAN, Princeton N. "China's Rising Role in Africa". Council on Foreign Relations, 21.07.2005, disponível em http://www.cfr.org/. 
MELVILLE, Chris; OWEN, Olly. "China and Africa: a new era of 'south-south cooperation'", Open Democracy, 07.07.2005, disponível em http://www.opendemocracy.net/globalization-G8/south 2658.jsp.

PAN, Esther. "China, Africa and Oil". Council on Foreign Relations, 26.01.2006, disponível em http://www.cfr.org/publication/9557/.

“A aposta brasileira na África”. Valor Econômico, 29.10.2007

"A Comunidade dos Países de Língua Portuguesa". Embaixada do Brasil em Lisboa, Novembro 1994.

"A corrida da África: a China sai na frente". Valor Econômico, 31.10.2007.

"Angola atinge primeiro lugar no fornecimento de crude à China". Portal das Empresas - Governo de Angola, 20.04.2008, disponível em http://www.angolainternet.ao/.

"Angola: China's African foothold". BBC News, 20.06.2006, disponível em http://news.bbc.co.uk/2/hi/africa/5080626.stm.

"As Perspectivas Econômicas de Angola depois da Paz". Angola Digital, 12.01.2006, disponível em http://www.angoladigital.net/sobrepais/.

"Cabo Verde: chineses investem 100 milhões de euros no llhéu de Santa Maria”. Agência Lusa, 07.03.2006, disponível em http://www.agencialusa.com.br/.

"Cabo Verde espera atrair mais investimentos chineses". Agência Lusa, 03.11.2006, disponível em http://www.agencialusa.com.br/index.php?iden=4544.

"China-Africa trade jumps by 39\%". BBC News, 06.01.2006, disponível em http://news.bbc.co.uk/.

"China anuncia investimento na agricultura de Moçambique". Agência Lusa, 23.03.2006, disponível em http://www.agencialusa.com.br/index.php?iden=409

"China dá apoio de $\mathrm{R} \$ 8,6$ mi e abre mercado à Guiné-Bissau". UOL Notícias, 03.01.2007, disponível em http://noticias.uol.com.br/economia/ultnot/lusa/2007/01/03/ult3679u1036.jhtm.

"China destaca Cabo Verde em parceria estratégica com a África". Agência Lusa, 07.03.2006, disponível em http://www.agencialusa.com.br/index.php?iden=115. 
"China In Angola. An Emerging Energy Partnership". The Jamestown Foundation, 13.11.2006, disponível em http://jamestown.org/news details.php?news id=205.

"China's global hunt for oil". BBC News, 09.03.2005, disponível em http://news.bbc.co.uk/.

"China's growing focus on Africa". BBC News, 17.01.2006, disponível em http://news.bbc.co.uk/.

"China offers package of aid measures for Africa". China Daily, 04.11.2006, disponível em http://www.chinadaily.com.cn/.

"China oferece 100 bolsas de estudo para a formação de quadros guineenses". Notícias Lusófonas, 01.08.2007, disponível em http://www.noticiaslusofonas.com/.

"China perdoa dívida Moçambicana". Portal do Governo de Moçambique, 08.02.2007, disponível em http://www.govnet.gov.mz/noticias/news folder politica/fevereiro2007/nots po 125 fev 07

"China's African Policy". Ministry of Foreign Affairs from the People's Republic of China, 12.01.2006, disponível em http://www.fmprc.gov.cn/eng/zxxx/t230615.htm.

"China's Quest for Resources". The Economist, 13.03.2008

"China's trade safari in Africa". Le Monde Diplomatique, May 2005.

"Comércio com China atinge 208 milhões USD". Portal do Governo de Moçambique, 20.04.2007, disponível em http://www.govnet.gov.mz/noticias/news folder econom neg/abril2007/nots en 317 abr 07.

"Conferência Ministerial de 2003 - Plano de Ação para a Cooperação Econômica e Comercial", 13.10.2003, disponível em http://www.forumchinaplp.org.mo/pt/2003.asp.

"Country Profiles". BBC News, disponível em http://news.bbc.co.uk/.

"Crescimento econômico chinês define agenda proativa para a África". Conselho Empresarial Brasil-China, 08.08.2006, disponível em http://www.cebc.org.br/003/00301063.asp?ttCD CHAVE=21161

"Dados gerais. Cabo Verde: Breve Apresentação", disponível em http://www.governo.cv/index.php?option=com content\&task=view\&id=52\&ltemi $\underline{d=62}$. 
"Economia e instituições 'extremamente frágeis' e dependentes de ajuda". MacauHub,

http://www.macauhub.com.mo/pt/news.php?ID=4347.

"Em Angola, onde falta tudo, boom do petróleo atrai novos negócios". Valor Econômico, 26.10.2007.

"Estudo de Mercado dos Países de Língua Portuguesa", Instituto de Promoção do Comércio e do Investimento de Macau, disponível em http://www.ipim.gov.mo/.

"Forum on China-Africa Cooperation - Beijing Action Plan(2007-2009)", Council on Foreign Relations, 16.11.2006, disponível em http://www.cfr.org/publication/12278/.

"Governante chinês considera bem sucedida visita a Angola". Jornal de Angola, 27/02/2005.

"História Cronológica da Guerra e Paz em Angola". Angola Digital, disponível em http://www.angoladigital.net/sobrepais/.

"Moçambique: China gerou mais de 11 mil empregos desde 1990". MacauHub, 08.05.2008, disponível em http://www.macauhub.com.mo/pt/news.php?ID=5304.

"O Renascimento Africano". O Estado de São Paulo, 17/12/2007.

"O país: História". Disponível em http://www.governo.cv/index.php?option=com content\&task=view\&id=53\&ltemi $\underline{\mathrm{d}=63}$.

"Plano de Ação para a Cooperação Econômica e Comercial (2007-2009) Segunda Conferência Ministerial", setembro de 2006, disponível em http://www.forumchinaplp.org.mo/pt/2006.asp.

"Plataforma da China para mercados africano, europeu e americano". Embaixada da República de Cabo Verde no Brasil, 04/12/2007, disponível em http://www.embcv.org.br/portal/modules/news/article.php?storyid=77.

"Política de Desenvolvimento do Setor Privado". Consulado Honorário da República da Guiné-Bissau, disponível em http://www.geocities.com/consuladogb/.

"Presidente da China em Moçambique para reforço da cooperação bilateral". Portal do Governo de Moçambique, 08.02.2007, disponível em http://www.govnet.gov.mz/noticias/news folder politica/fevereiro2007/nots po $122 \mathrm{fev} 07$ 
"Primeiro ministro garante: as relações diplomáticas entre São Tomé e Taipé vão manter-se". Jornal Vitrina São Tomé e Príncipe, 19.03.2008, disponível em http://www.vitrina.st/AsAprova.htm.

"'Queremos que a China nos ensine a pescar', diz Guiné-Bissau". Agência Lusa, 03.11.2007, disponível em http://www.agencialusa.com.br/index.php?iden=4542.

"Resumo Histórico". Portal do Governo de Moçambique, disponível em http://www.govnet.gov.mz/Mozambique/resHistorico.

"São Tomé e Príncipe evita virar as costas para a China". UOL Notícias, 13.12.2007, disponível

em http://noticias.uol.com.br/ultnot/lusa/2007/12/13/ult611u76017.jhtm.

"Trade links boost African economic growth". China Daily, 04.11.2006, disponível em http://www.chinadaily.com.cn/.

"Visando petróleo, chineses alimentam a reconstrução". Folha de São Paulo, 05.11.2007.

"War-scarred Angola seeks a future". BBC News, 04.04.2006, disponível em http://news.bbc.co.uk/. 